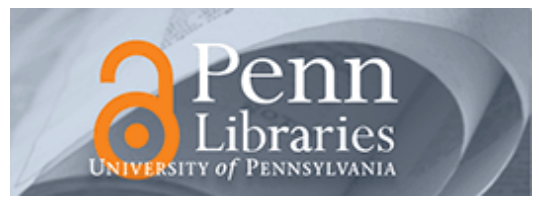

Studies in Visual Communication

Volume 9

Issue 2 Spring 1983

Article 3

1983

Iconography of a Scandal: Political Cartoons and the Eulenburg

Affair

James D. Steakley

Recommended Citation

Steakley, J. D. (1983). Iconography of a Scandal: Political Cartoons and the Eulenburg Affair. 9 (2), 20-51.

Retrieved from https://repository.upenn.edu/svc/vol9/iss2/3

This paper is posted at ScholarlyCommons. https://repository.upenn.edu/svc/vol9/iss2/3

For more information, please contact repository@pobox.upenn.edu. 
Iconography of a Scandal: Political Cartoons and the Eulenburg Affair 


\title{
Iconography of a Scandal: Political Cartoons and the Eulenburg Affair
}

\author{
James D. Steakley
}

From 1907 to 1909, imperial Germany was by turns amused and mortified by a series of journalistic exposés, libel trials, and Reichstag speeches, all of which turned upon the alleged homosexuality of the chancellor and of two distinguished members of the entourage of Kaiser Wilhelm II. Taken together, these discourses constituted the most stunning scandal on the level of domestic politics in the history of the Second Reich (1871-1918). National honor was palpably at stake, and the German people were willing and even eager to judge the kaiser not by the company he kept but by the robustly paternal image he sought to project (see Figure 1). It was defensively asserted from the rostrum of the Reichstag that "no one can doubt the moral earnestness of our Kaiser and his consort, whose family life provides the entire country with a fine model." "Y Yet Philipp Prince zu Eulenburg-Hertefeld - the central figure in the scandal, which thus became known as the Eulenburg Affair — was, to all appearances, himself a happily married man, and for a time the nation was brought uncomfortably close to having to consider the disturbing implications of the kaiser's penchant for frequent hunting trips and the annual holiday cruise on the royal yacht in exclusively male company (see Figure 2). The implications were abundantly clear to the initiator of the attacks on Eulenburg, Maximilian Harden for he possessed documentary evidence that probably would have sufficed to expose and depose the kaiser. ${ }^{2}$ He chose never to make use of it.

National attention shifted to yet another grave scandal late in 1908, this time affecting the Reich's foreign diplomacy rather than its domestic politics. The kaiser had given a bombastic interview to the Daily Telegraph of London in which, typically, he offered unwanted advice and rashly expatiated on his peaceable vision of future relations between Germany and its archrival on the seas, Great Britain. Its publication unleashed a storm of outrage in the Reichstag, both from implacable foes of Britain and from those who simply expected the kaiser to exercise reasonable discretion when discussing German strategy. Shaken by his obvious blunder and the ensuing furor, Wilhelm was all too happy to flee his duties for the regular November hunt at the Black Forest estate of an aristocratic confidant. It was here that the chief of the Military Secretariat, Dietrich Count von HülsenHäseler, donned a ballerina's tutu and was performing a pas seul as his customary after-dinner entertainment when he suddenly dropped to the floor, dead of

James D. Steakley is an Assistant Professor in the Department of German at the University of Wisconsin-Madison and a contributing editor of New German Critique.

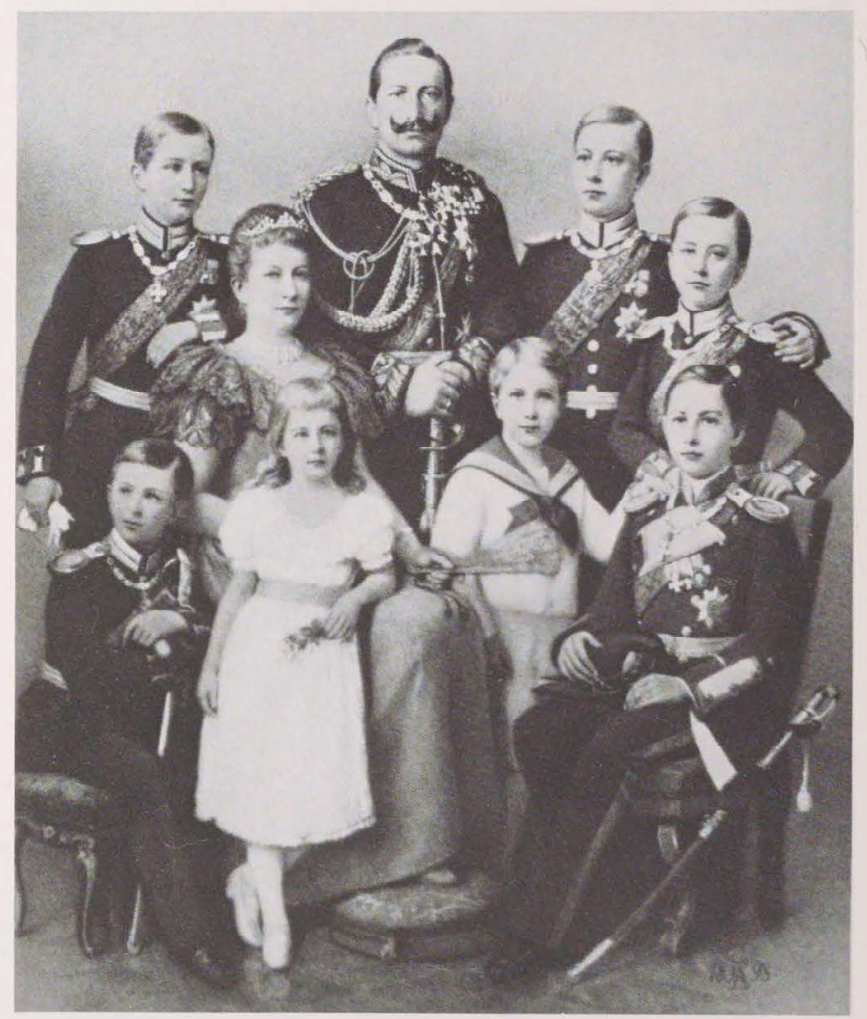

Figure 1 Kaiser Wilhelm II as an idealized paterfamilias, 1898. "This sort of cozy photograph of the Imperial family sold by the million throughout Germany" (Kurtz 1970:5).

a heart attack. "The incident with all that it implied was hushed up" (Balfour 1964:290), but the combination of events proved too much for Wilhelm, who shortly suffered a nervous breakdown. One dinner party guest who witnessed these events wrote: "In Wilhelm II I saw a man who, for the first time in his life, with horror-stricken eyes, looked upon the world as it really was" (Czernin von und zu Chudenitz 1919:54).

Like the bizarre death of Hülsen-Häseler, the entire Eulenburg Affair has been discreetly hushed up in all but the most recent historiography. Bound by disciplinary restraints, diplomatic historians have given due attention to the international controversy but imposed what amounts to a scholarly blackout on its domestic counterpiece - a disparity all the more striking in light of Maximilian Harden's astute observation that the Eulenburg scandal was "the underlying cause" of the Daily Telegraph affair (Holstein 1963:no. 1151). This embarrassed silence has been even more obvious among German than among non-German historians, ${ }^{3}$ manifesting an understandable reluctance to wash the nation's dirty linen in public (see Figure 3 ). 
It is in the nature of scandal, however, to catapult sexual conduct out of the supposedly inviolable private sphere into the public arena, thus generating discourses on sexual politics and influencing both attitudes and actions. In the specific instance of the Eulenburg Affair, the long-range consequences were so severe that the scandal defies dismissal as a mere episode. French, British, and American historians have linked the events of 1907-1909 to a far-reaching shift in German policy that heightened military aggressiveness and ultimately contributed to the outbreak of World War I (cf. Hull 1982b; Baumont 1933; Röhl 1976:35-53). Such insights were by no means unknown to earlier observers. Writing in 1933, for example, Magnus Hirschfeld argued that the outcome of the whole sordid affair was "no more and no less than a victory for the tendency that ultimately issued in the events of the World War (Hirschfeld 1933:2). And in a bitterly racist vein, Wilhelm himself fulminated in 1927 that the scandal had been started "by international Jewry" and marked "the first step" of a conspiracy that led in 1918 to German defeat and his abdication. ${ }^{4}$ Yet these assessments of the long-range effects of the Eulenburg Affair, however apt or grotesque they may be, overlook the vital dimension of the scandal's more immediate, short-term impact on the moral life of the German nation. While hindsight can link the scandal with momentous events that occurred years later, such interpretations were obviously unavailable to contemporary observers struggling to draw their own set of conclusions.

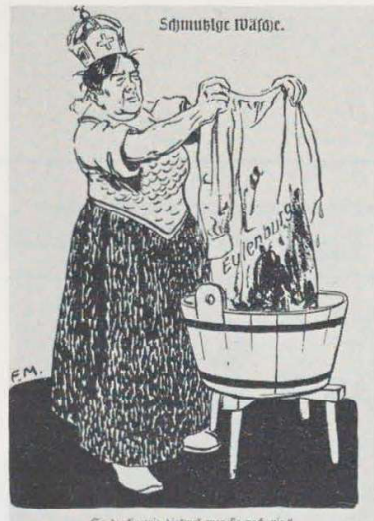

Figure 3 (caption above) Dirty Laundry. (caption below) "It's never been this filthy before." From Der wahre Jacob (Stuttgart), no. 570 (May $16,1908)$, p. 5819.

As the most tumultuous cause célèbre of its era (see Figure 4), the Eulenburg Affair provoked a flood of press coverage, ranging from articles and editorials in daily papers to pocket digests of courtroom testimony. Political pamphlets and broadsides appeared, and virtually every facet of the shocking revelations was minutely depicted in political cartoons as the courtroom drama unfolded. ${ }^{5}$ Drawn from a variety of periodicals ranging from the far left to the far right of the political spectrum, ${ }^{6}$ the cartoons selected for inclusion here provide a unique access point for a socio-historical analysis of the Eulenburg Affair by illuminating some of the values, anxieties, and cultural norms of Wilhelminian society. Apart from the antiSemitic interpretation of events (see Figure 5) advanced in reactionary völkisch circles and adopted by Wilhelm, the pictorial handling of the scandal reveals a remarkable degree of uniformity. A handful of images appears repeatedly, a phenomenon that cannot be adequately attributed to the possibility of artis-
Figure 2 The kaiser and select members of his entourage on the royal yacht Hohenzollern, 1897. Wilhelm, wearing sunglasses, is seated in the front row; immediately behind him, wearing a white cap, is Philipp zu Eulenburg. Kuno von Moltke, also wearing a white cap, is the third figure to the right of Eulenburg: At the kaiser's side, wearing a dark cap, is Georg von Hülsen. From Eulenburg 1931: facing p. 32.

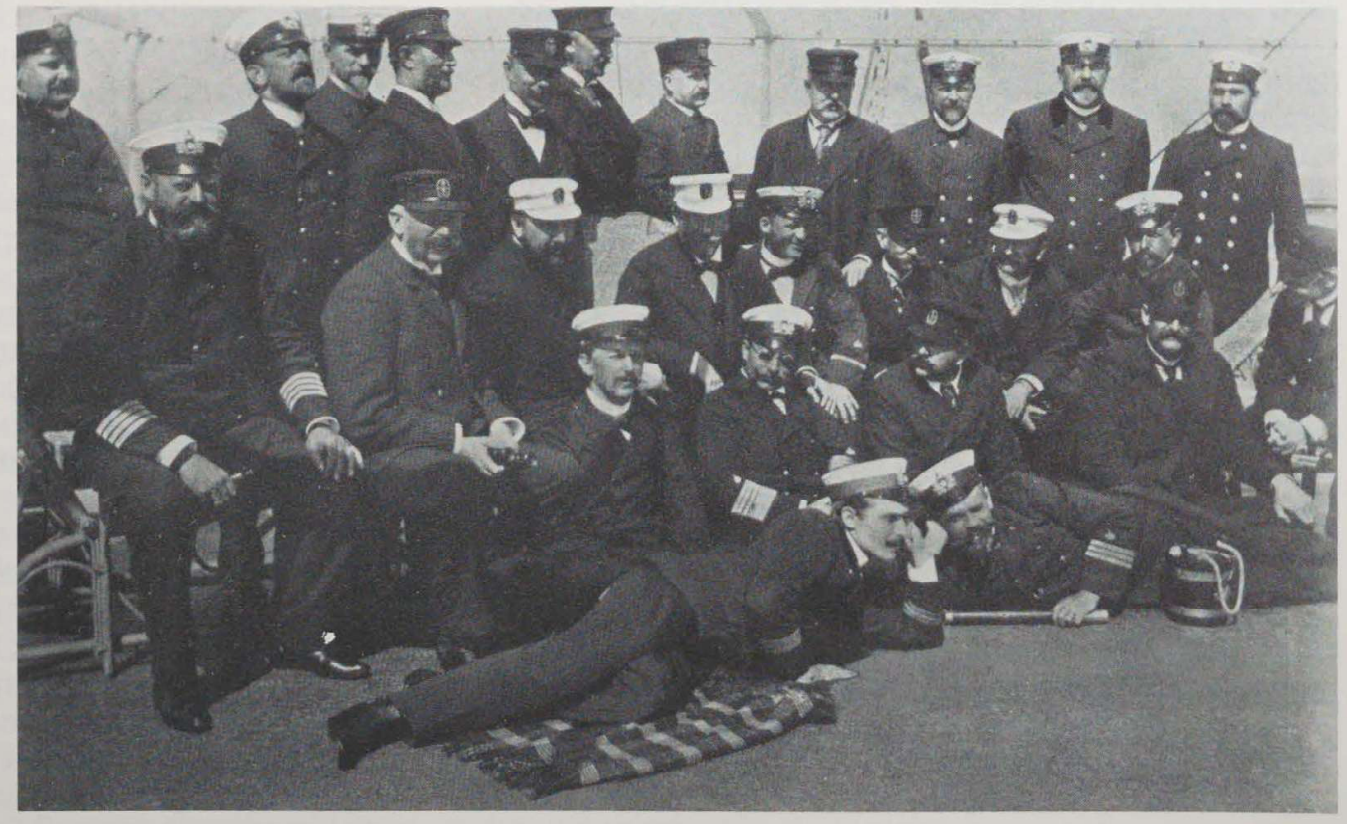




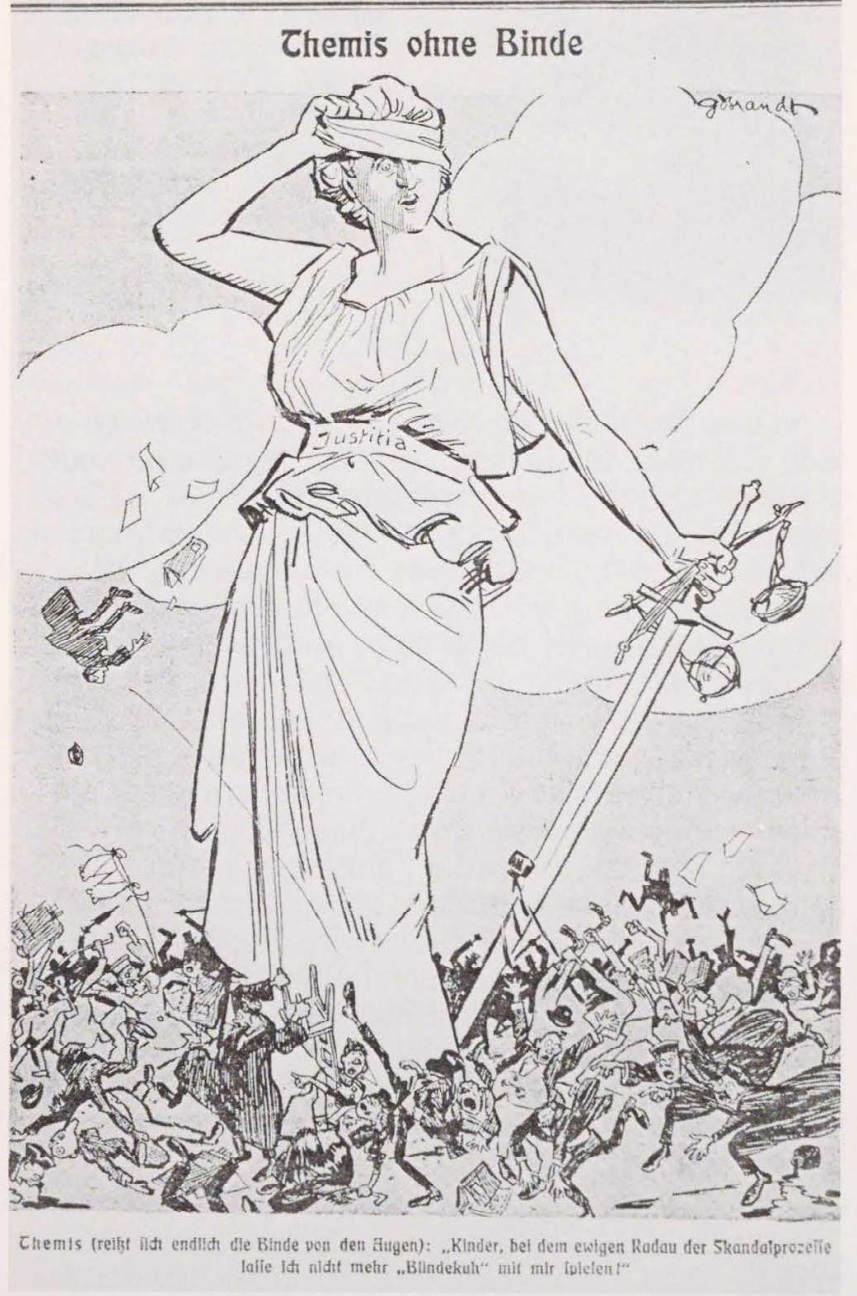

Figure 4 (caption above) Justice without a Blindfold. (caption below) Justice (finally ripping the blindfold from her eyes): "Hey, with the constant racket about the scandal trials, I'm going to quit playing blind man's bluff!" From Kladderadatsch (Berlin), vol. 60, no. 44 (December 3 , 1907), Beiblatt 1, p. 1.

tic plagiarism or the favored use of certain motifs (such as the cuirassiers' uniform; see Figures 12, 19, 24,32 ) that emerged in court testimony. Among the cartoons' recurrent themes are the threats to national honor and security posed by the spread of decadence among the ruling class, the corruption of military discipline, and the inversion of traditional sex roles. The common denominator of these concerns was a profound sense of cultural pessimism that transcended party divisions and was only superficially belied by the humor of the caricatures.

\section{Background Events}

The starting point of the Eulenburg Affair can ultimately be traced back to the rupture between the political visions and programs of Chancellor Otto von Bismarck and those of Kaiser Wilhelm II. The "Iron Chancellor" had single-mindedly — some would say brilliantly - shaped Germany's destiny by founding the Second Reich and for almost two decades guiding the nation to great-power status under Wilhelm I, who was content to serve as a mere figurehead. Shortly after succeeding to the throne in 1888 , Wilhelm II dismissed Bismarck and energetically instituted "personal rule," reclaiming for the monarch constitutional powers that had heretofore devolved upon the chancellor. The young kaiser saw himself as the embodiment of the Reich's historical mission, but he struck seasoned political observers as brash and incompetent, and insiders were alarmed by his precarious mental balance-impressions that were only deepened by the passage of time. In a display of compensatory bravado, Wilhelm dismantled Bismarck's Realpolitik, based on a dense network of treaties designed to guarantee the European balance of power, and replaced it with a confrontational Weltpolitik, which promised to gain the Reich its rightful "place in the sun" by mounting a naval fleet and aggressively pursuing overseas expansion. But Bismarck's sophisticated statesmanship was actually supplanted by vacillatory bluster, for Wilhelm surrounded himself with a mixed retinue of military and civilian advisers whose outlooks diverged widely; tugged in competing directions, he proved incapable of synthesizing a consistent stance on foreign affairs.

The preeminent figure in Wilhelm's civilian entourage during the 1890s was Eulenburg, a member of the diplomatic corps whose anti-imperialist outlook and willingness to seek an accommodation with the "hereditary enemy," France, earned him the undying enmity of hawkish Gallophobes in the upper echelons of both the military and the Foreign Office. He seemed untouchable, however, for it was rumored in court circles "that His Majesty loves Philipp Eulenburg more than any other living being," ${ }^{17}$ and Wilhelm swiftly promoted his "bosom friend"8 to an ambassadorship. Even prior to his dismissal, Bismarck's assessment of the relationship between the two was such that it could "not be confided to paper"; therefore, he explained in a letter to his son, "I will not write much that I intend to tell you" (Bismarck 1964:525). In 1892, after his retirement, Bismarck also disclosed his suspicions to Maximilian Harden and elaborated on his concern in acidulous terms: "There are supposed to have been some quite good generals among the cinaedi [a pejorative Greek word for homosexuals], but I have yet to encounter any good diplomats of the sort." Fourteen years would elapse before Harden's public disclosure of Eulenburg's 


\section{Die (PolitiR des Jüen IJarden.}

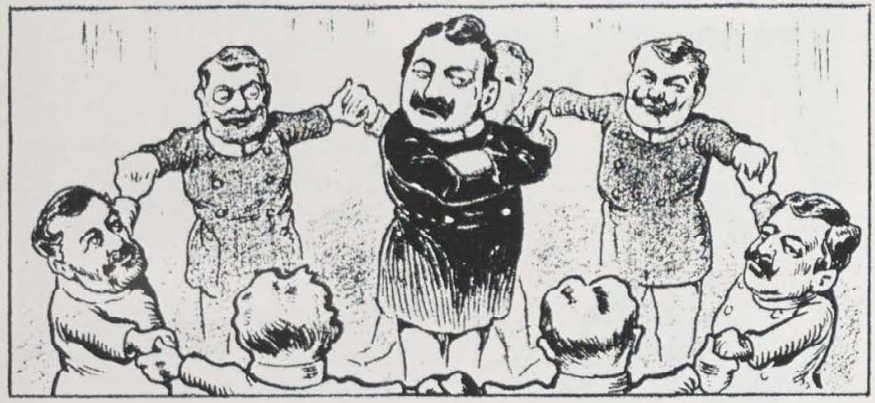

Diefe th Ming bat er zerbrodien

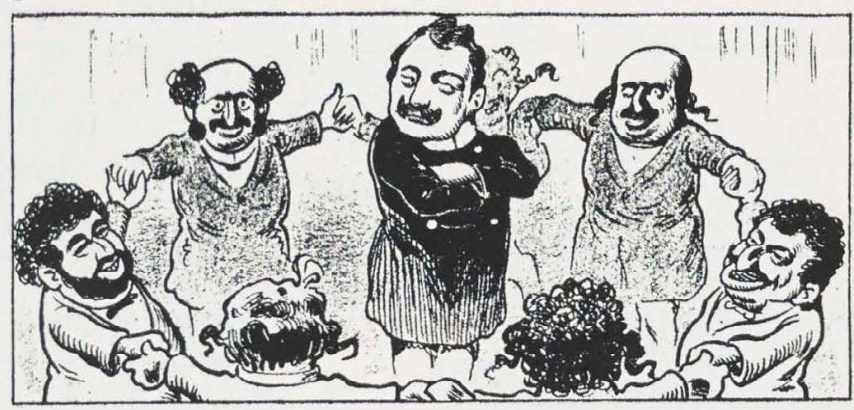

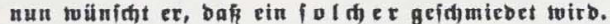

Figure 5 (caption above) The Politics of the Jew Harden. (captions below) This ring he broke-Now he wants this kind to be forged. From Kikeriki (Vienna), vol. 47, no. 90 (November 10, 1907), p. 2.

homosexuality, but the motive was unaltered and widely shared: breaking his "mesmeric power" over the kaiser's heart and mind. ${ }^{10}$ And indeed, his removal from the entourage signaled a decisive and fateful shift from competing civilian and military influences on German foreign policy to the outright dominance of "preventive war" advocates.

Were one to restrict the investigation of the Eulenburg Affair to the cartoons it inspired, it would be easy to arrive at the erroneous conclusion that Eulenburg came under fire solely because of his homosexuality and to lose sight entirely of the political background just outlined. Of some 250 cartoons that I examined, only one (Figure 6) sets the scandal in the context of German foreign policy. Its caption refers to the climate of "entente and détente" circulating in Europe and suggests that Germany-symbolized as a "well-known old soldier" with a Wilhelminian mustache-has wearied of its status as a bellicose outsider among nations. The soldier bears flowers and candies intended for the young man peaceably playing a flute, the quill on his lap symbolizing the signing of international accords. The soldier fears, however, that presenting his gifts will cause him to be (mis)labeled a homosexual by Dr. Magnus Hirschfeld, the sexologist whose expert testimony helped shape the verdict in three libel trials during the course of the scandal.

That this is the only cartoon explicitly linking homosexuality and anti-imperialism is perhaps less surprising when one considers that all the other cartoons originally appeared in journals that dealt simultaneously with a broad range of foreign and domestic affairs. A panoptic review of the sources would enable one to discern certain ramifications of the Eulenburg Affair that remain largely invisible when the cartoons are examined in isolation. Because political cartoons generally comment on or embellish news reports, they are documents rather than historiography, historical in nature rather than mode. They are reliable indicators of the response to new information that is still being digested (a process they stimulate), but their full operational effectiveness relies upon a context of cultural and historical assumptions embedded but not necessarily inscribed in their images. In the case of the Eulenburg Affair, the element left unspoken and unpictured resides in the quest for power by his adversaries; their weapons, not their motives, are revealed in the cartoons. Indeed, the Eulenburg Affair was prompted neither by Eulenburg's homosexuality nor even by his politics. As his loyal and courageous wife remarked to Hirschfeld during a court recess,

"They are striking at my husband, but their target is the Kaiser" (Hirschfeld 1933:2). The All-Highest Person rarely appeared in any of the German cartoons (and in none selected for inclusion here), while he figured prominently in numerous foreign cartoons - trying more or less successfully to distance himself from the stench of scandal (see Figures 7 and 8).

Although Eulenburg had a formidable number of aristocratic opponents, including the kaiser's sister, ${ }^{11}$ these figures preferred to intrigue behind the scenes and to leave the public vendetta to a bourgeois individual, Maximilian Harden (see Figure 9). At the height of the scandal, one homosexual nobleman asked indignantly (and with no little trepidation): "Does this Jew actually rule in Prussia, deposing generals and ambassadors?"1? Harden was perhaps the most accomplished and, to use his word, "effective" political commentator of an era when German Jews were more strongly represented in journalism than in any other profession. ${ }^{13}$ After meeting him, Bismarck blithely remarked that Harden "was not at all like a Jew" and thereby alluded to a current stereotype: the word Jew was then synonymous with hack journalist 


\section{Deinlich}

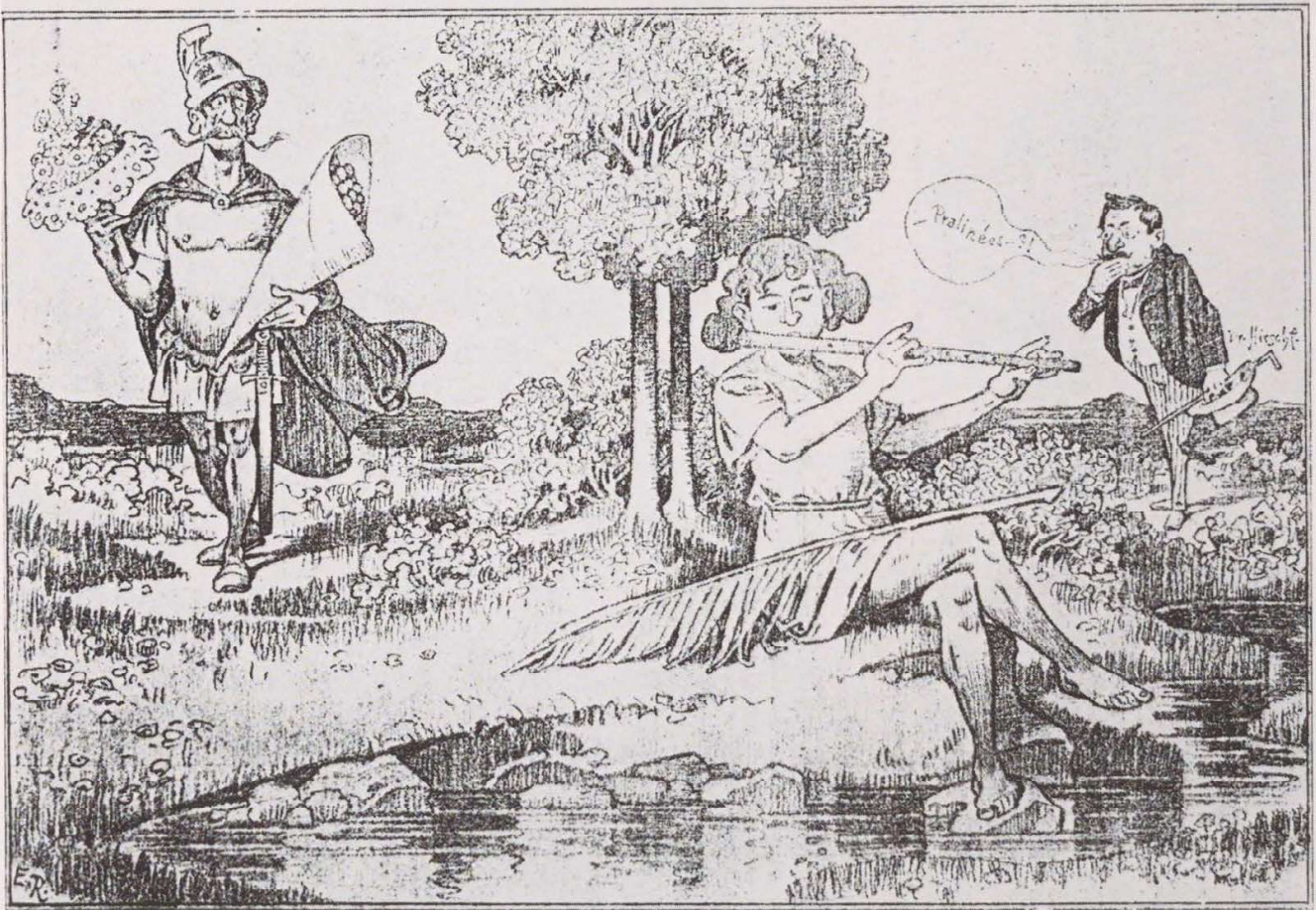

Europa fteht unterm Zeiđhen der Ententes und Détentes; ein bekamuter alter militär verzwelfelt an feinem Beruf und denkt daran, auch den Frieden zu fucten. Itur fürditet er noch, in diefer verieucten Zeit, bei feinen Annäherungsveriuchen die willenichaftlict =humanitäre llacturede.
Figure 6 (caption above) Embarrassing. (caption below) Europe has entered an era of entente and détente; a well-known old soldier despairs of his profession and thinks of seeking peace too. It's just that in these pestilential times, he fears that any approach will lead to scientific-humanitarian slander. (The figure at the right is labeled Dr. Hirschfeld, and he is asking, "Sweets?") From Kladderadatsch (Berlin), vol. 60 , no. 52 (December 29, 1907), Beiblatt 4, p. 3. (quoted in Weller 1970:39; cf. also Young 1959:43) Harden edited and largely wrote by himself Die Zukunft, a fiercely independent Berlin weekly, in which he called for progressive domestic reforms and for a coherent foreign policy combining Bismarckian diplomacy and expansionistic Weltpolitik. A relentless gadfly of Wilhelm's personal rule, Harden was repeatedly jailed and fined for lèse majesté, ${ }^{14}$ but he always returned to the thick of the fray.

Harden was equally vitriolic in his published attacks on Eulenburg, which began appearing in 1893 and continued intermittently throughout the decade. He refrained from sexual innuendo because he upheld the classic distinction between public and private spheres, a patrimony of bourgeois liberalism to which he was devoted as a beneficiary of Jewish emancipation. But his patience was wearing thin by 1902, and he quietly issued what amounted to an ultimatum: if Eulenburg did not resign from public life, his secret life would be exposed. Eulenburg capitulated to this blackmail at once, for retirement seemed not too dear a price to pay to avoid disgrace: suffering ill health, mourning the death of his mother, and disheartened
Figure 7 (caption above) The First Clean-up. (caption below) Poor Germania, you'll have to start all over again next week. From Le Cri du peuple (Brussels), November 3, 1907.

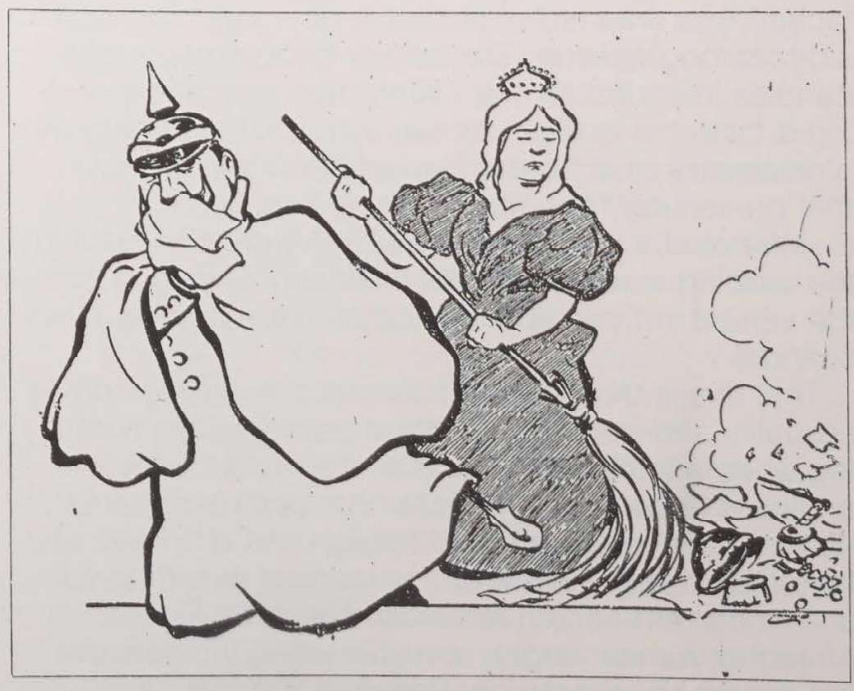




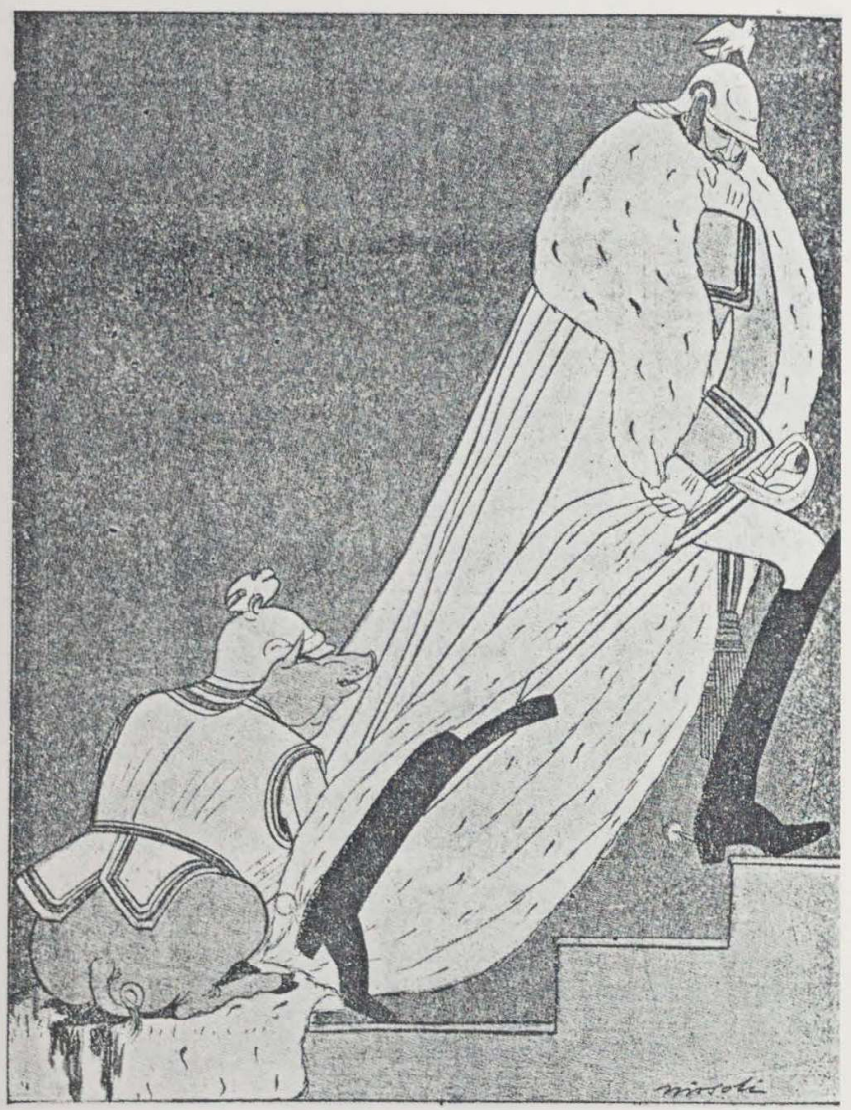

Figure 8 (caption below) "It wouldn't do any harm if the imperial cape, which reaches to the bottom of the steps to throne, were really caught in it." From Pasquino (Turin), November 3, 1907.

Figure 9 (caption above) The Song Is Over! (caption below) "There we are. I'm glad l've finally dumped out my cart." (The signpost bears an imperial German eagle and the legend: "Dumping manure and garbage is forbidden.") From Der Nebelspalter (Zurich), November 2, 1907

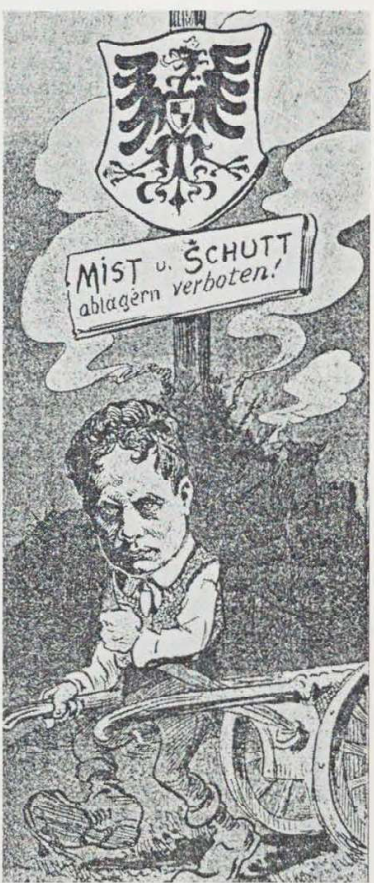

by a cooling in his relationship with Wilhelm (who may have feared exposure himself), the 55-year-old prince proved quite willing to yield his ambassadorship in Vienna and to retreat to Liebenberg, his country estate in the Mark Brandenburg, where he would spend the next years as a virtual recluse. Personally vindicated and genuinely relieved that exposing Eulenburg had not been necessary, Harden shared with his aristocratic allies the fond hope that a new and better day was dawning for the Reich.

It was therefore a rude jolt when, in late 1905 and 1906, Eulenburg ventured to resume his contacts with foreign diplomats and the kaiser, whom he invited to a shoot at Liebenberg. Moreover, Eulenburg's cautious rehabilitation coincided with a major foreign policy fiasco, Germany's yielding hegemony over Morocco to France at the Algeciras Conference, which it was all too easy to pin on Eulenburg's rising star. Finally, rumors began circulating that Eulenburg coveted the post of chancellor, and Harden renewed his attack, in stronger language than ever: two articles published in November of 1906 linked Eulenburg, "this unhealthy, late-romantic visionary"
(Harden 1906a:266), with General Kuno Count von Moltke, military commandant of Berlin. They in fact had a long-standing friendship, and this was by no means Harden's first attack on Moltke, who had suffered the ignominy of having his nickname, Tütü, revealed in Die Zukunft five years earlier. ${ }^{15}$ In the second of the articles, ominously entitled "Dies irae," the two were identified only as the "Harpist" (Eulenburg was a widely performed amateur composer) and "Sweetie" (due to Moltke's weakness for chocolates [see Figure 6]; "sweet" was moreover a vernacular term for homosexual). ${ }^{16}$ They engaged in a brief dialogue in which they wondered agitatedly whether Harden would dare to reveal "even more" and agonized over the reaction of "Darling" (Wilhelm) to their exposure (Harden 1906b:291). ${ }^{17}$ Eulenburg beat a hasty retreat, removing to Switzerland and dispatching an intermediary to mollify Harden and avert further revelations.

And there matters remained for the moment. Journalists sensed that an important story was breaking, and newspapers throughout the country reported on Harden's second article or even reprinted it in full. 


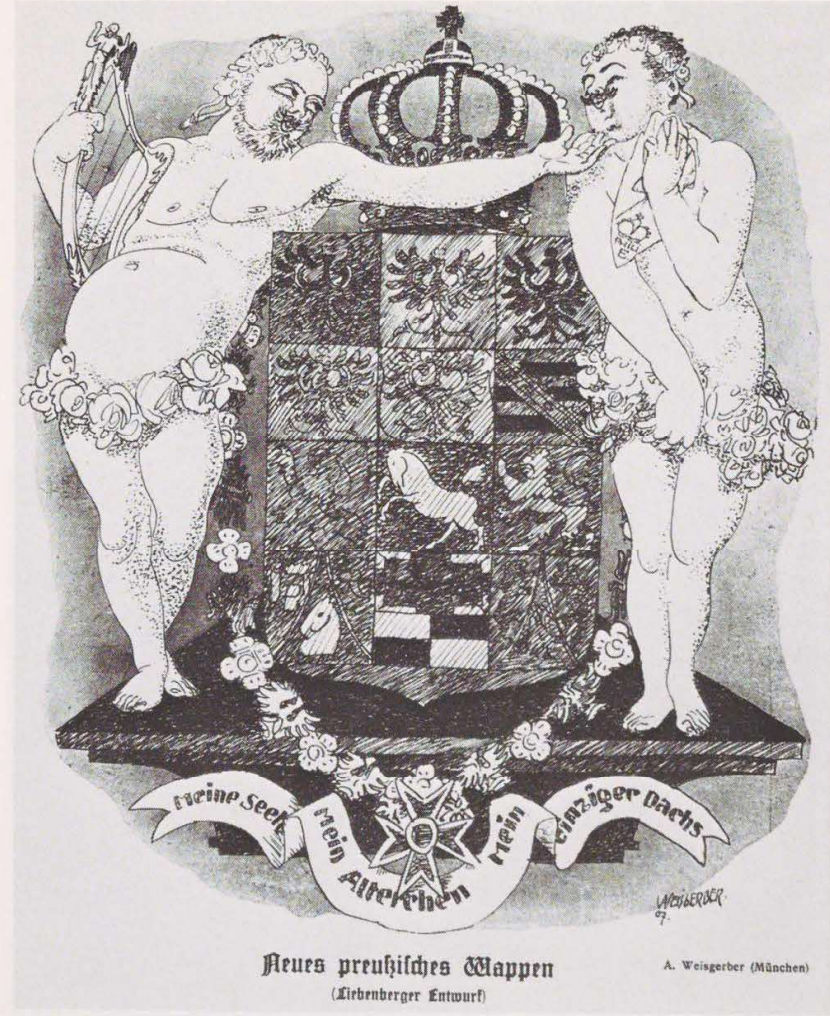

Figure 10 (caption below) New Prussian Coat of Arms (Liebenberg Design). (The motto on the scroll reads: My sweetheart, my loverboy, my one and only cuddly-bear.) From Jugend (Munich), vol. 11, no. 45 (October 28, 1907), p. 1028.

Figure 11 (caption above) The Latest Fashion. (caption below) Traveling salesman from Berlin: "Here are some lovely soldier's pants from Potsdam-at a bargain price. 'Tütü' brand. My name is Lynar." Proprietress: "You pathetic, crazy, lost man. Go back where you came from with your Schweinehund." (Lynar's hat has a Paragraph 175 label; the woman is an innkeeper at the Hotel for Political Asylum, i.e., Switzerland.) From Der Nebelspalter (Zurich), November 16, 1907.
But Harden's warning had been so carefully encoded that its meaning was cryptic to all but those immediately involved, and another six months would elapse before the identities of Sweetie and the Harpist became public knowledge and they could appear as heraldic figures in a "New Prussian Coat of Arms" (Figure 10). Harden's decision to breach the barrier between public and private was a difficult one and was reached due to an ensemble of factors. First, various aristocratic intriguers continued to egg him on. Second, military circles were embarrassed by a flurry of lesser scandals. They cumulatively convinced Harden that homosexuality was becoming rampant, and he hoped a deathblow to Eulenburg would stem the tide. The figures were indeed alarming: within the preceding three years, courts-martial had convicted some twenty officers of homosexual conduct, and 1906-1907 witnessed six suicides by homosexual officers ruined by blackmail (Brand 1975:[2]). ${ }^{18}$ One officer stationed with the elite Garde du Corps Regiment in Potsdam, Major Johannes Count von Lynar (see Figure 11), was charged with molesting his aide-de-camp, while a second officer charged with homosexuality, Lieutenant General Wilhelm Count von Hohenau (see Figure 12), was not only Commander of the Garde du Corps but also a blood relative of the kaiser. The final factor prompting

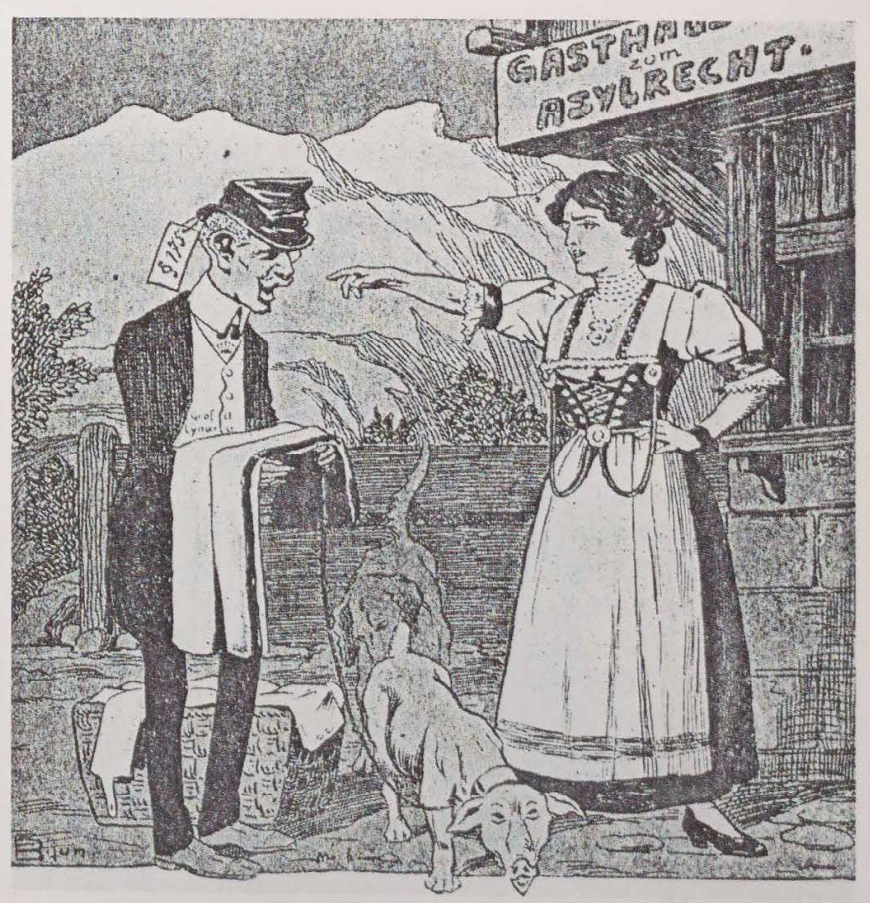




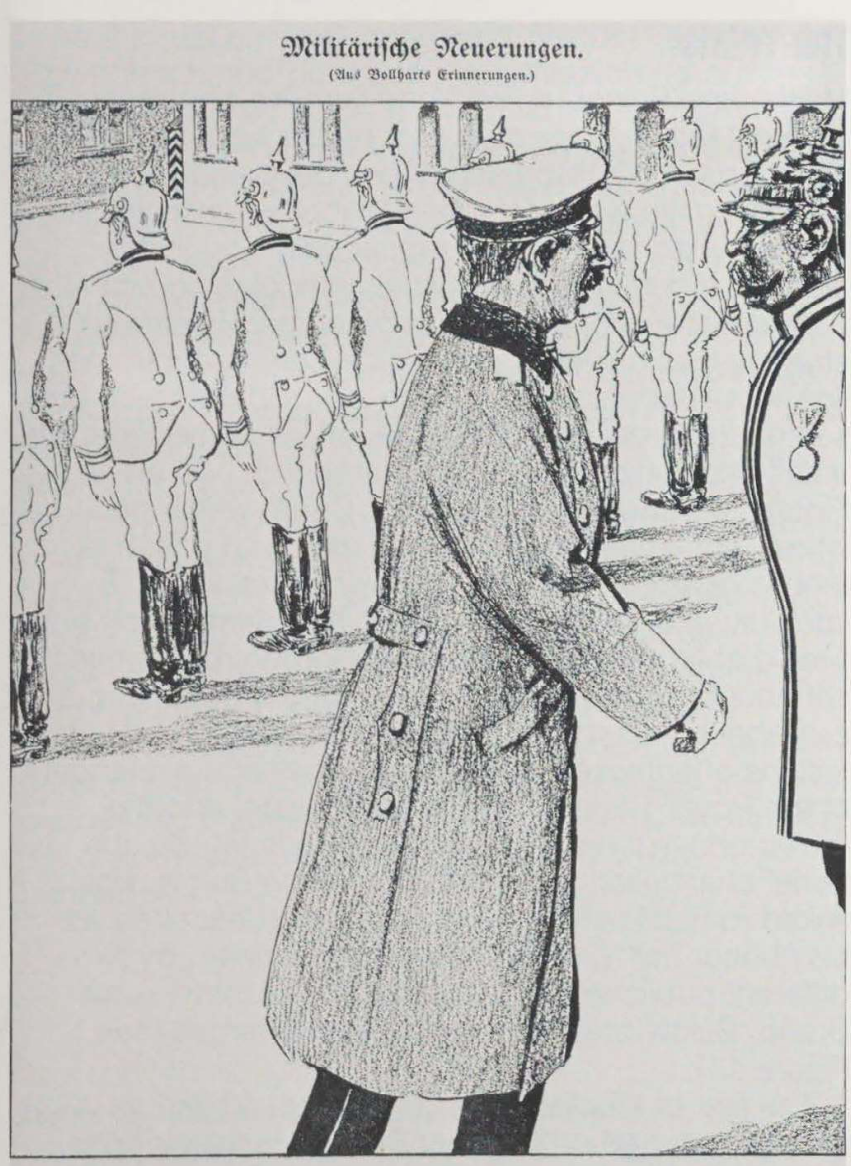

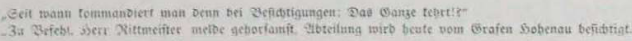

Figure 12 (caption above) Military Innovations. (caption below) "Since when is an about-face order given for inspections?!" "At your service, Captain-reporting that the division is being inspected today by Count Hohenau." From Der wahre Jacob (Stuttgart), no. 447 (November 26, 1907), p. 5621.

Figure 13 (caption above) The Camarilla. (caption below) The German Michel: "Is it truly, totally dead for good?" From Ulk (Berlin), vol. 36, no. 46 (November 15, 1907), p. 1.
Harden was Eulenburg's foolhardy decision to return from Switzerland to be initiated into the High Order of Black Eagle. This honor appeared all the more inappropriate when, one month later, Friedrich Heinrich, Prince of Prussia, regretfully declined investiture as Grand Master of the Order of the Knights of St. John with the shocking explanation that his homosexual proclivities made him unsuited for the prestigious post. Convinced that the body politic was under assault, Harden scathingly denounced Eulenburg as a pervert on April 27, 1907, noting acidly that since his "vita sexualis [was] no healthier" than Friedrich Heinrich's, he should have the decency to follow the prince into exile (Harden 1907a:118). He had been forced to expose this secret, so he argued, because of the political "side-effect of abnormal (even if idealized) friendship among men" (Harden 1907c:423). He quoted Moltke as having said: "We have formed a ring around the Kaiser that no one can break through" (see Figure 5) (Harden 1907b:369).

As anxious speculation about the homosexual camarilla intriguing against the national interest began to fill the German press, the royal suite realized it would finally have to act. The kaiser was no reader, and it had been easy for his cabinet and entourage to keep him blissfully ignorant of the growing scandal. Now, however, the 25-year-old crown prince-an officer in

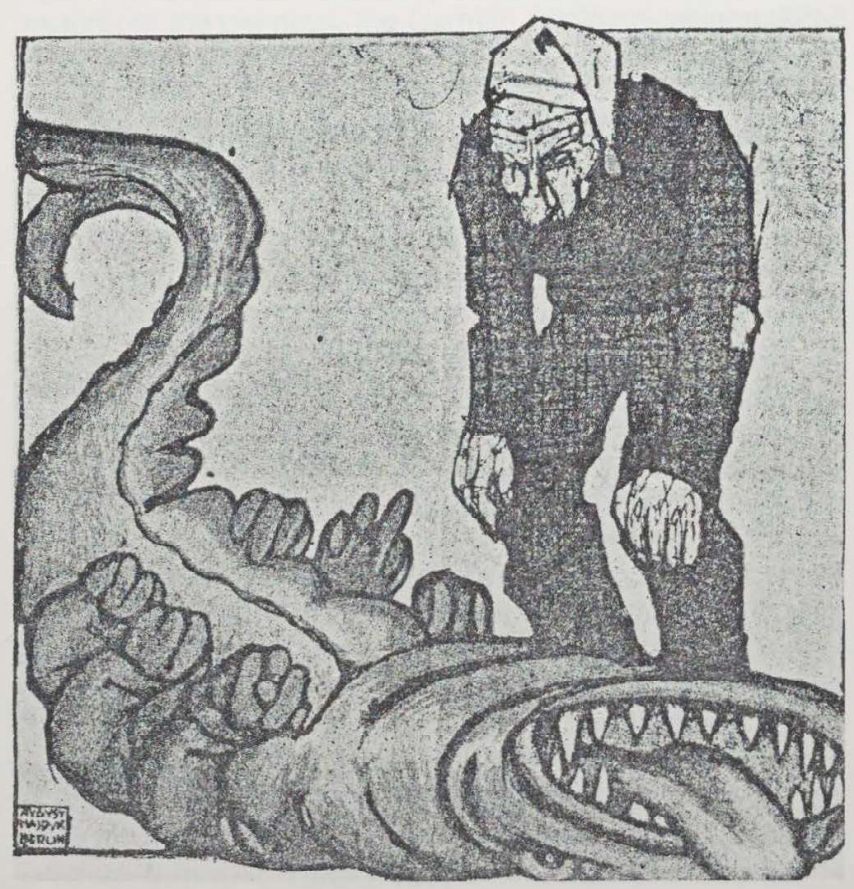




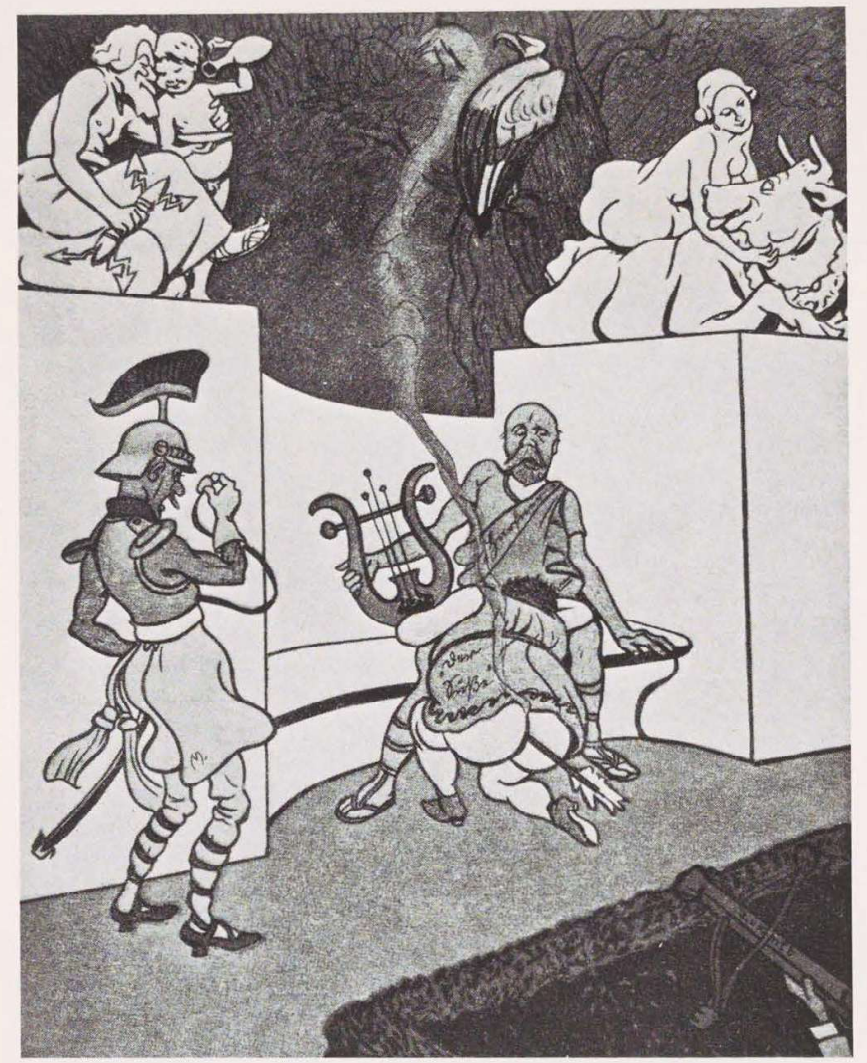

Figure 14 (caption above) Sodom's End. (caption below) It wasn't exactly Tell's shot, but it hit the mark. (The crossbow is labeled Zukunft, the kneeling figure is identified as "Sweetie," and the seated figure is "the Harpist." The standing figure is identified as M., for Moltke, for Harden's cryptic references led many journalists to think that

"Sweetie" was Lecomte. The statuary shows Zeus and Ganymede on the left, Europa and the steer on the right.) From Der wahre Jacob (Stuttgart), no. 547 (July 9, 1907), p. 5453; original in color.

the Garde du Corps - was selected to break the news to his father. On May 2, he marched in to the appointment armed with back issues of Die Zukunft. He later reported that an expression of utter horror and despair had spread across his father's features and charitably attributed this to disgust at the mention of homosexuality (Wilhelm 1922:14-15). ${ }^{19}$ After regaining his composure, Wilhelm hastily conferred with Hülsen-Häseler and the minister of police affairs, who presented him with a carefully edited list of approximately fifteen prominent aristocrats adjudged homosexual by the Berlin vice squad; it had been pared down from several hundred to spare the kaiser's feelings. ${ }^{20}$ Apparently finding their names on the list, the kaiser commanded Hohenau, Lynar, and Moltke to re sign their commissions, while Eulenburg was told either to exculpate himself or to go into exile. Pleased that the kaiser had acted so decisively, the nation hoped that the camarilla was eliminated (see Figure 13) and hailed Harden as a modern Wilhelm Tell, the liberator of his fatherland (see Figure 14). In a hollow gesture derived from the aristocratic code of honor, Moltke promptly challenged Harden to a duel, acting out a ritual that was not simply anachronistic but by now illegal.

\section{The Trials}

Moltke and Eulenburg retained lawyers who pursued different tacks. Their dismissal by the kaiser had led many observers to presume their guilt, and Moltke's attempt to file a suit for criminal libel against Harden was rebuffed by the state prosecutor, who instead advised him to file for civil libel, thus placing him at a considerable procedural disadvantage. Eulenburg's strategy was cleverer and avoided direct confrontation with Harden: after denying his culpability, he presented the local district attorney of his home area with a self-accusation of violating Paragraph 175 (see Figures 11 and 39) of the Penal Code, which punished "unnatural vice" between men with prison sentences of anywhere from one day to five years. By late July, the DA had completed his investigation and, predictably, cleared Eulenburg. Harden meanwhile set about preparing his defense for the upcoming civil libel trial, and Berlin was further shaken by accusations of homosexuality leveled against the intendant of the Royal Theater, Georg von Hülsen, and the crown prince's equerry, von Stückradt. Finally, the imperial chancellor, Bernhard Prince von Bülow, was linked romantically with his secretary (described as his "better half"), Privy Councillor Schecfer, by two different publicists; and against one of them, Adolf Brand, Bülow pressed criminal libel charges (see Figure 15).

The first of the cases to go to court, Moltke v. Harden, opened on October 23. The lackluster performance of Moltke's lawyer contrasted sharply with Harden's brilliant defense. Three chief witnesses took the stand: Moltke's former wife, who had divorced him nine years earlier; Dr. Magnus Hirschfeld, the forensic expert on homosexuality; and an enlisted man named Bollhardt. Lily von Elbe testified that, in two years of marriage, conjugal relations had occurred only on the first two nights; on the few other nights they had shared a bed, Moltke had sometimes placed a pan of water between them, apparently to discourage her advances (see Figure 16). She reported that her husband had once espied a handkerchief (see Figure 10) left behind by Eulenburg and had warmly pressed it to his lips, murmuring "Phili, my Phili!" Moltke had variously addressed Eulenburg as "my sweetheart, my loverboy, my one and only cuddly-bear" (see Figures 10 and 38), and the two had referred to Wilhelm as their "Darling." Eulenburg had always vehemently opposed their marriage, she added, and her husband spent more time with him than with her-including Christmas Eve; but she had not suspected the worst, since the very existence of homosexuality was unknown to her at the time. Still, the two had behaved in such a blatant way that her 10-ycarold son (of a previous marriage) had taken to imitating their "revolting" mannerisms with the servants. ${ }^{21}$ 
As the trial entered its second day, an "enormous crowd" gathered before the courthouse and police reinforcements had to be summoned to maintain public order; the crowd grew larger day by day, and an "army" of German and foreign reporters encamped at the scene. A soldier, Bollhardt, testified that sexual relations between officers and enlisted men in the Potsdam regiments were common knowledge (see Figure 17, which notably appeared prior to the scandal) and went on to confess in unprintable detail his participation in champagne orgies at Lynar's villa (see Figure 18), stating that he had seen both Hohenau and Moltke there. The hushed courtroom was fascinated by Bollhardt's report on the powerful sex appeal of the white pants and kneehigh boots of the cuirassiers' uniform: any guardsman who ventured to wear it in public was virtually certain to be approached by men soliciting homosexual intercourse (see Figure 19). "But that's forbidden now, you know," he remarked, unwittingly provoking an outburst of hilarity. After the mirth had subsided, he explained his meaning: due to importunities, wearing the uniform after nightfall had recently been banned. 22

Figure 15 (caption below) Bülow: "My little Moor, you'd never be such a poorly trained dog." (The departing figure is labeled Brand.) From Kladderadatsch (Berlin), vol. 60, no. 43 (October 27, 1907), p. 164.

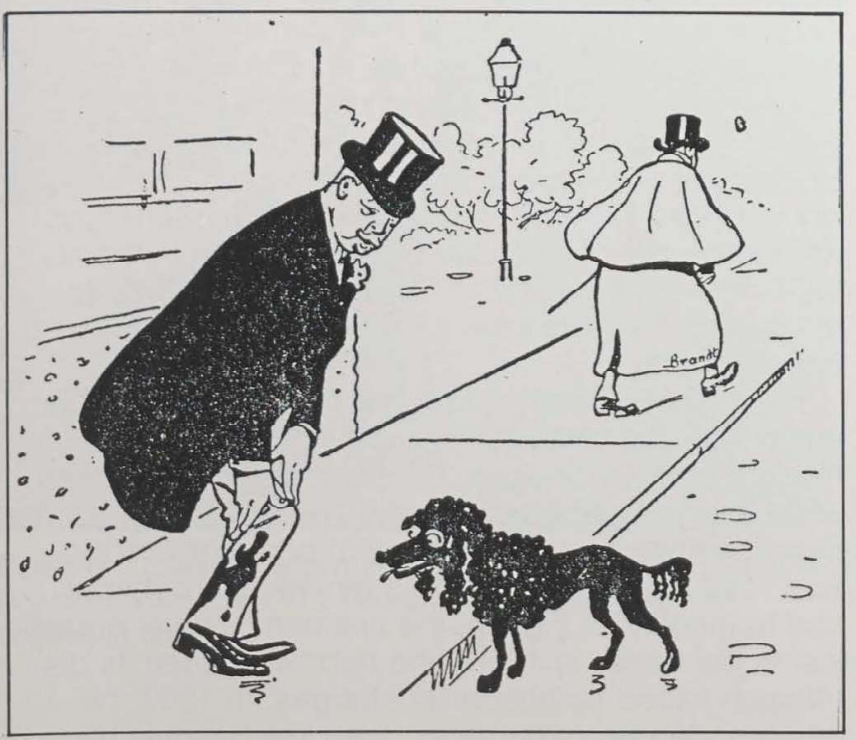

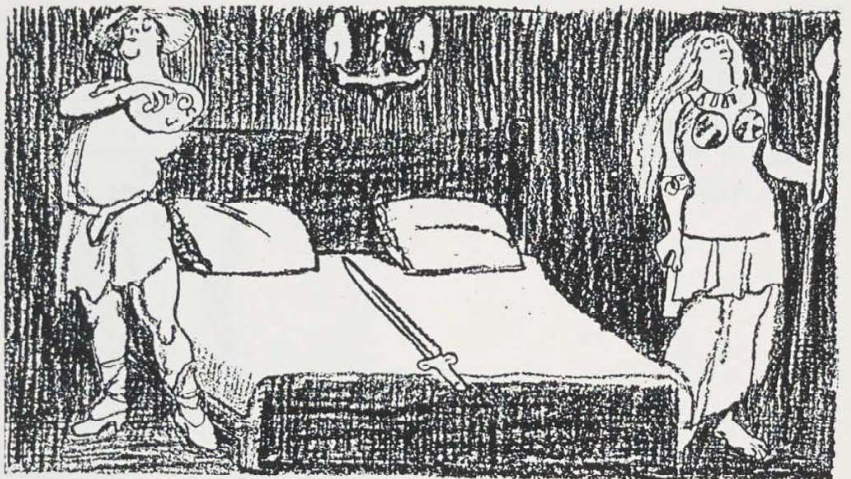

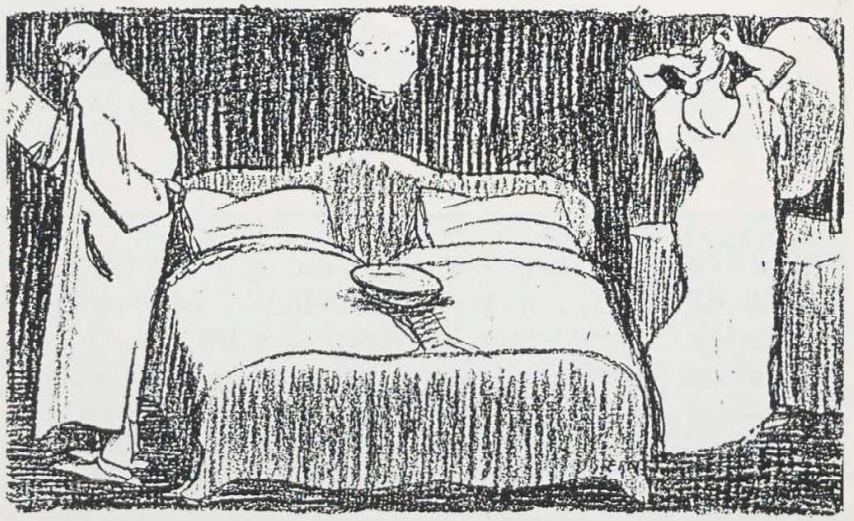

Figure 16 (caption above) Heroes. (caption below top picture) In the old days, the German Siegfried put a naked sword between himself and his spouse. (caption below bottom picture) Nowadays, it's a little pan of water. From Lustige Blätter (Berlin), vol. 22, no. 45 (November 5, 1907), p. 10. 
Figure 17 (caption below) Tantalus. From Der wahre Jacob (Stuttgart), no. 525 (September 4, 1906), p. 5156.

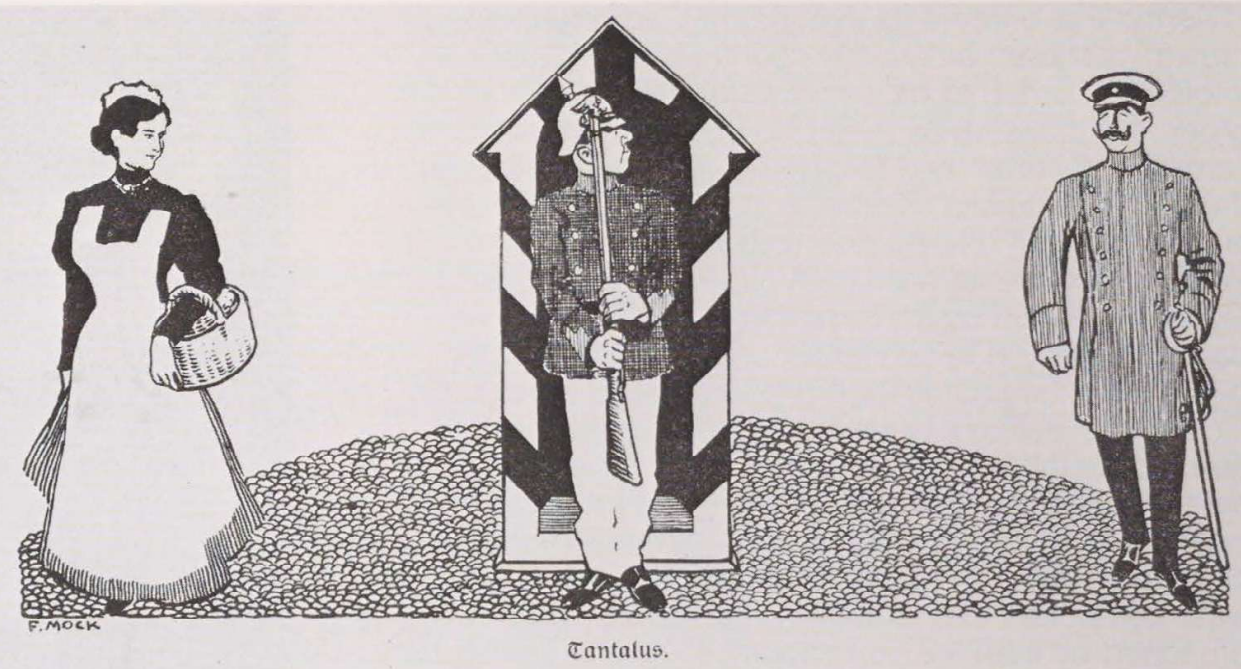

The final witness to take the stand was Hirschfeld whose very appearance-immediately captured in numerous cartoons (see especially Figure 20) seemed to exemplify a Jewish stereotype. He had served for the past ten years as chairperson of the Scientific-Humanitarian Committee (see Figure 6), an organization that campaigned for the repeal of Paragraph 175, and his courtroom appearance on Harden's behalf tended to strengthen the association between Jews and the unprecedented publicity being given to homosexuality. (In the following days, handbills advertising anti-Semitic lectures were distributed in front of his apartment [Hirschfeld 1907d:232].) Basing his remarks on Lily von Elbe's testimony and on his observation of Moltke in the courtroom, Hirschfeld asserted that the plaintiff had a "feminine side" that "deviated from the norm, i.e. from the feelings of the majority." In particular, his treatment of his wife, his devotion to Eulenburg, his "sensitivity" for the arts, and his use of makeup (visible in the courtroom) permitted the deduction that Moltke's "unconscious orientation" could "objectively" be labeled "homosexual," even if he had never violated Paragraph $175 .^{23}$ In his closing argument, Harden stressed that he, too, had never charged Moltke with lawbreaking but only with suffering from a "mawkish, unmanly, sickly condition" and that he had revealed Moltke's orientation not to profit from sensationalism (sales of Die Zukunft were up dramatically; see Tresckow 1922:184-185), but for political ends (Young 1959:101, 104).

On October 29, the court handed down its verdict: the plaintiff's homosexuality had been confirmed and the defendant was therefore acquitted of libel, court costs falling to the plaintiff. According to Hirschfeld, "a storm of moral outrage" swept through the country, but it was curiously two-pronged, directed both at decadent "upper classes" and at the Jewish bearers of bad tidings (Hirschfeld 1907c:1519). A cloud of suspicion settled more firmly than ever over Eulenburg, and Moltke's disgrace seemed irremediable, when an unexpected development took place. The trial was voided due to faulty procedure and, in a reversal of the earlier standpoint, the state prosecutor called for a retrial against Harden, this time on grounds of criminal libel. This announcement came just a few days before the opening of the second major trial, which was to pit Chancellor Bülow against Adolf Brand. It appears that the German judiciary now regarded Harden's acquittal as a serious blunder that tended to undermine public confidence in the regime. ${ }^{24}$ Convinced that it would be child's play to find Brand guilty of libel in the upcoming case, the judiciary intended to make an example of him, then mount an aggressive prosecution against Harden in the retrial. In its determination to restore respectability to the ruling class, the justice system was henceforth far from impartial.

The Bülow v. Brand case was handled quickly, the entire trial and sentencing occurring on one day, November 6 . Once again the courtroom was packed, while throngs gathered outside. The first to testify was Brand, whose extensive history of prior convictions was read into the record. This remarkable publicist had founded Der Eigene, the first homosexual periodical in the world, in 1896, and had twice seen its distribution halted by obscenity charges. In 1902, he had founded an organization that, like Hirschfeld's group, aimed at repealing Paragraph 175. Here the similarities with Hirschfeld ended, but-as the latter noted - the two were subsequently lumped together or actually confused by the German press. 

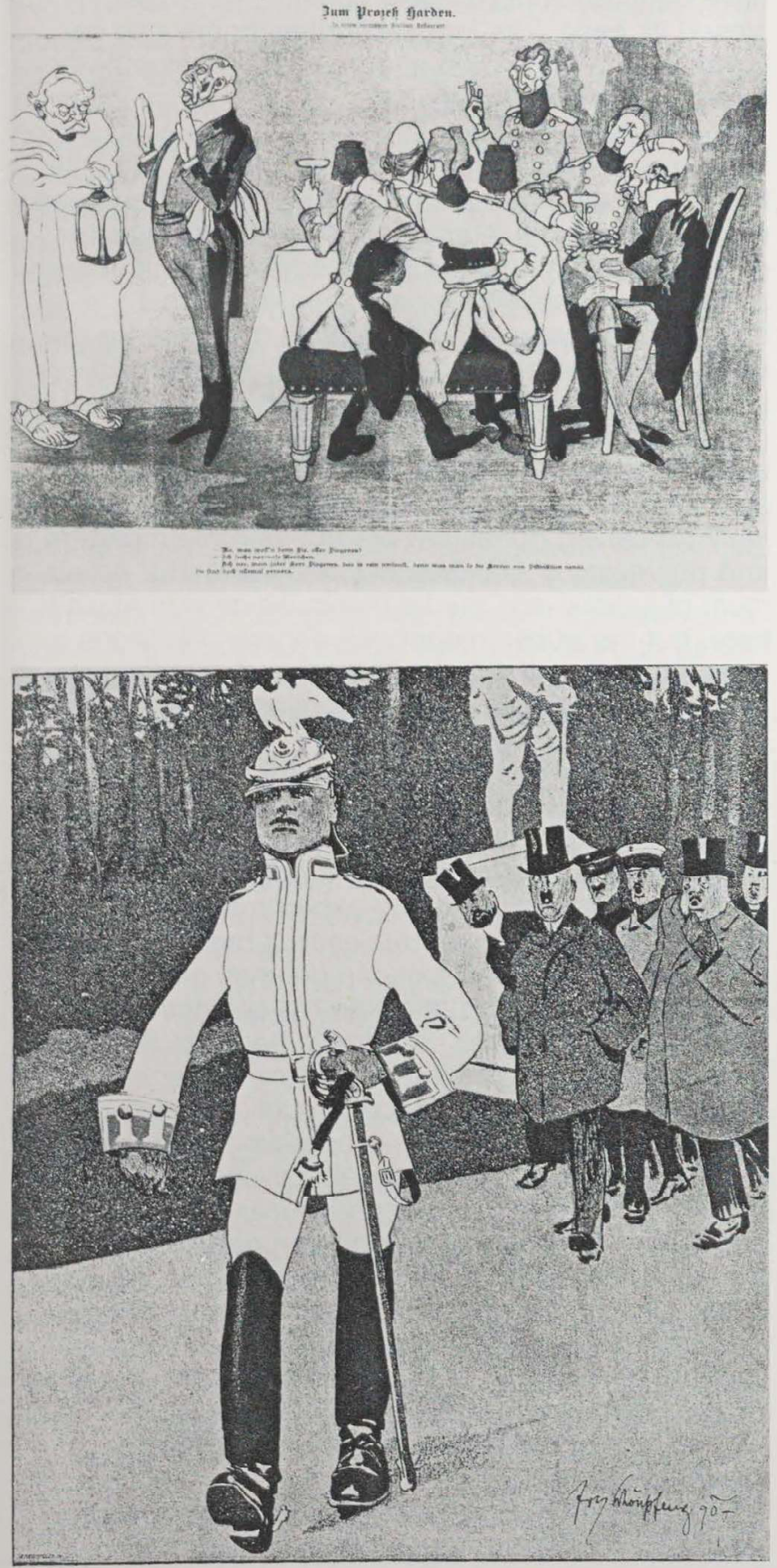

Flgure 19 (caption below) Hero-Worship. From Die Muskete (Vienna), vol. 5, no. 111 (November 14, 1907), p. 49; original in color.
S Figure 18 (caption above) On the Harden Trial. (In an exclusive Berlin restaurant.) (caption below) "Well, what do you want, old Diogenes?" "I'm searching for normal people." "Oh no, my good man, that's pointless, for what you might call gentlemen of distinction are all perverse." From Figaro (Vienna), vol. 51, no. 44 (November 2, 1907), pp. 660-661.

Figure 20 (caption above) Panic in Weimar. (caption below) "Wolfgang, let go of my hand! Dr. Magnus Hirschfeld is coming!" From Jugend (Munich), vol. 11, no. 48 (November 19. 1907), p. 1089.

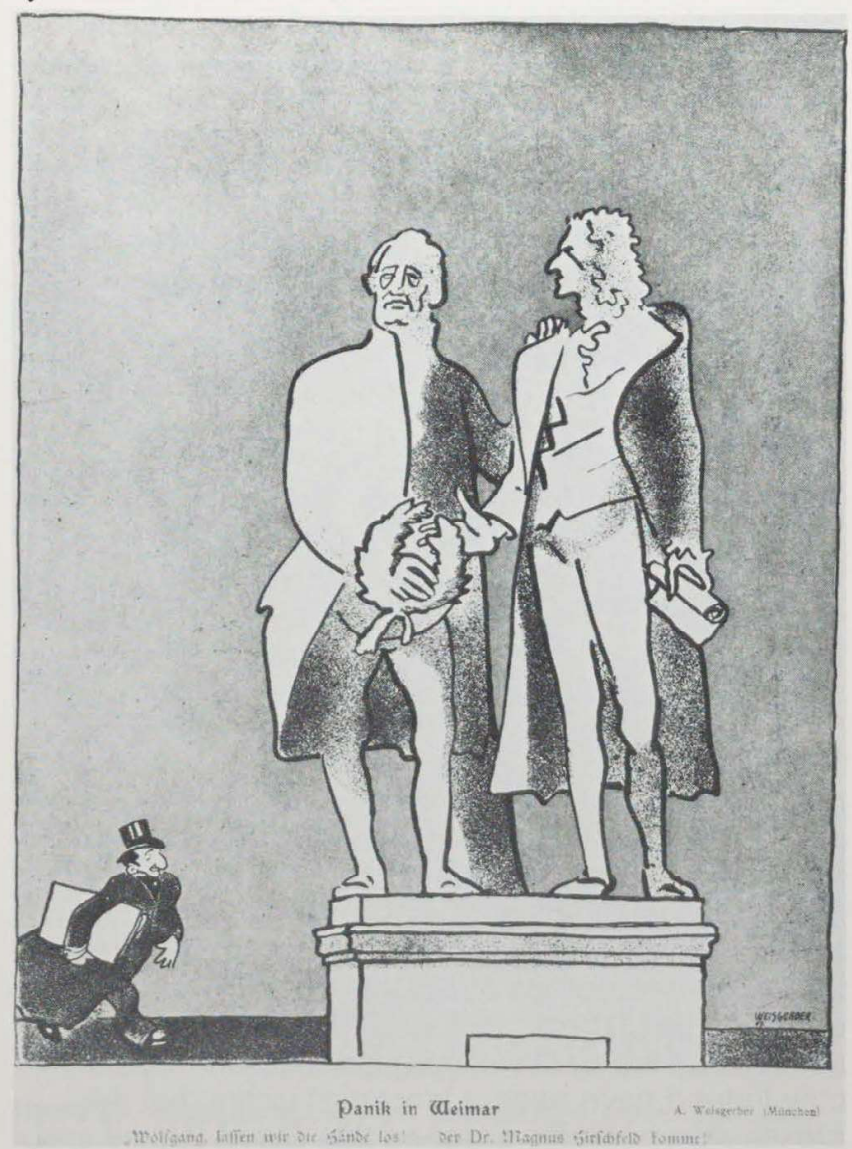


(Hirschfeld 1907d: 230-232). ${ }^{25}$ Brand was charged with authoring and distributing a libelous leaflet, in which he alleged that Bülow had been blackmailed because of his homosexuality, that he had embraced and kissed Scheefer at all-male gatherings hosted by Eulenburg, and that he was morally obligated as a homosexual to use his influence for the repeal of Paragraph 175. Brand maintained the truth of these claims and argued that he had not intended to insult Bülow by calling him a homosexual, since he had a positive view of those who shared his own sexual orientation. He had exposed Bülow with the political goal of hastening the repeal of Paragraph 175, for he had come to believe that this could only be achieved by creating martyrs - the strategy of "the path over corpses." Finally, borrowing an argument from Harden's defense, he claimed that he had only labeled Bülow's orientation, not accused him of lawbreaking. ${ }^{26}$

Bülow took the stand next, airily dismissing Brand's imputations and demanding an exemplary punishment. He made the gratuitous observation that, while his private life was beyond reproach, the same could not be said of Eulenburg, about whom he had heard unsavory rumors. The next witness was Eulenburg, who passed over Bülow's slur in silence and merely asserted that he had never hosted parties such as those described by Brand; he simultaneously used the opportunity to swear, as had Bülow, that he had never violated Paragraph 175. He appealed to public sympathy by arguing that Hirschfeld's sophistic system of sexual "nuances" could turn any innocent friendship into a source of calumny. Brand spoke again, expressing his esteem for Eulenburg's vision of ideal friendship and inserting a jarring political note: the campaign of vilification against Eulenburg could ultimately be traced to Bülow, who saw in him a rival for the post of chancellor. This assertion, already suggested by Bülow's disparaging remark, has been confirmed by diplomatic historians (Hull 1982b:121-127; Cole 1982:250-251); but, at the moment, Brand was speaking the unspeakable by exposing the chancellor as an intriguer. Thus, when Eulenburg was asked whether he gave any credence to Brand's analysis, the question was instantly ruled out of order by the judge, who claimed to be "determined to keep politics out of this case."27 The proceedings briefly took another unplanned turn when the head of the Berlin vice squad testified that Bülow may indeed have been a blackmail victim, but the prosecution hurriedly dropped this line of inquiry and instead obliged Brand to identify his sources. These were numerous, but the prosecution focused only on one: Brand claimed that Hirschfeld had spoken to a mutual acquaintance about Bülow's blackmail problem. When Hirschfeld then testified that he had never engaged in such a conversation (and he may well have perjured himself in doing so), ${ }^{28}$ the prosecution closed its case. The judge withdrew briefly and returned with a conviction and an eighteen-month prison sentence for libel.

The Brand v. Bülow trial made a mockery of justice, but the nation was gratified by its outcome and little inclined to scrutinize the procedure. Brand had been railroaded, and he later pointed out that he was the sole individual actually imprisoned as a result of the scandal. He was, in any case, convinced that the cause of homosexual emancipation, to which he devoted his life, needed martyrs; and his months in prison strengthened his martyr complex. His fate suggests that public opinion was beginning to rally around the established order and against those Jewish and homosexual publicists who were increasingly perceived not as saviors but as rumormongers and purveyors of filth (see Figures 9 and 15). An element of judicial and media manipulation was at work here, but the public responded eagerly. While the onus fell especially hard on Hirschfeld, Harden was at greater risk because of his upcoming trial on criminal libel charges.

The third trial opened on December 18 and lasted for two weeks, casting a pall over the holiday season. Lily von Elbe was placed back on the stand, and the state prosecutor destroyed the credibility of her earlier testimony by summoning expert medical witnesses who declared her a classical hysteric. Both Moltke and Eulenburg spoke in defense of the spirit of male friendship and attacked the distinction Harden and Hirschfeld had drawn between homosexual orientation and practices as mere chicanery. Intimidated by the about-face in public opinion and the obvious direction of the proceedings, Hirschfeld was reduced to a national laughingstock (see Figure 20) when he formally retracted his initial forensic opinion, feebly claiming that it had been predicated on the assumed truth of Elbe's testimony. Even Harden's claim to have acted from political motives was now discounted as a red herring, and the verdict handed down on January 4, 1908, became a foregone conclusion: Moltke's reputation was cleared, while Harden was convicted of libel and sentenced to four months in prison. ${ }^{29}$

Delighted by this turn of events, the kaiser envisioned a complete rehabilitation of Moltke and Eulenburg, planning for them a greater role than ever in his entourage (Zedlitz-Trützschler 1924:212). A semblance of judicial evenhandedness was created later that month when Lynar was convicted and Hohenau acquitted by a court-martial. ${ }^{30}$ The German press breathed a sanctimonious sigh of relief that public discussion of sexual matters was at an end and braced itself for a decline in sales to its sensation-hungry readership (see Hirschfeld 1908b:656-657). After six months of revelations and 
two months of triais, most observers prematurely concluded that the Eulenburg Affair was over. To be sure, the scandal had taken its toll: in the winter of 1908 , all the major parties involved-Moltke, Lily von Elbe, Eulenburg, Harden, Hirschfeld, Brand-suffered illnesses brought on by sheer exhaustion (Hirschfeld 1908b:651); the kaiser was near a nervous breakdown (Balfour 1964:276). But the nation underestimated the resourcefulness of Harden, who was motivated not just by opposition to the rehabilitated camarilla but now, as well, by vengefulness.

By testifying under oath in the second and third trials that he had never violated Paragraph 175 , Eulenburg had perjured himself. ${ }^{31}$ Harden faced the challenge of producing incontrovertible evidence so as to force the state prosecutor into action. In an elaborate legal ruse, Harden colluded with an ally, the Bavarian editor Anton Städele, who published a fraudulent article alleging that Harden had received a million Marks in hush money from Eulenburg to desist in his attacks. Harden then sued Städele for libel and turned the court proceedings into a forum for presenting his evidence on Eulenburg. Arranging for a trial outside of Berlin, in anti-Prussian Munich, was also part of the devious strategy.

With little advance fanfare in the press, the Harden Städele trial was convened and completed on April 21, 1908. Harden had subpoenaed Georg Riedel, a Munich milkman, and Jakob Ernst, a Starnberg farmer and sometime fisherman on the Bavarian lakes where Eulenburg had vacationed in earlier years. Since the statute of limitations had expired, Riedel freely admitted that in 1881, while serving in the military, he had once engaged in sexual relations with Eulenburg, who later made him gifts of money and also introduced him to Moltke. The second witness, Ernst, had more on his conscience and initially denied any wrongdoing. But, persıaded by the judge that swearing a false oath would lead to punishments in this world and the hereafter, he haltingly confessed that in 1883 as a 19-year-old, he had likewise been seduced by Eulenburg. Ernst later revealed that this incident initiated a long-term sexual relationship with the prince that had continued until quite recently (see Figure 21). During these years, Ernst had led a double but apparently charmed life as a respectable family man in Starnberg and as Eulenburg's intimate companion in Liebenberg, Munich, Berlin, and on princely vacations in Garmisch, Meran, Zurich, Rome, the Riviera, and Egypt (Harden 1913:252-253). The court's verdict was anticlimactic: Städele was convicted of libel and sentenced to a 100 Mark fine (which was covertly reimbursed by Harden).

Harden's real victory became evident in the stunned public reaction to the Munich trial. Gradually, a welter of opinions began to emerge. To some,

Eulenburg seemed disgraced beyond repair; one close friend forthrightly suggested he commit suicide. ${ }^{32}$ Others gave credence to Eulenburg's claim that Riedel and Ernst must have been paid by unknown enemies to give false testimony; Harden was suspect to many. And finally, public response was characterized by a certain jadedness, a conspicuous lack of interest when compared with the high emotions aroused by the first trials. ${ }^{33}$ Nonetheless, the socialists put the judiciary on notice that they would be closely monitoring the state prosecutor's response for signs of class justice, a legal double standard for aristocrats and commoners. ${ }^{34}$ With considerable reluctance, the state prosecutor moved into action: Eulenburg was arraigned on perjury charges on May 7, 1908, and two weeks later the imperial Supreme Court overturned Harden's libel conviction in the Moltke case on procedural and substantive grounds and called for a second retrial.

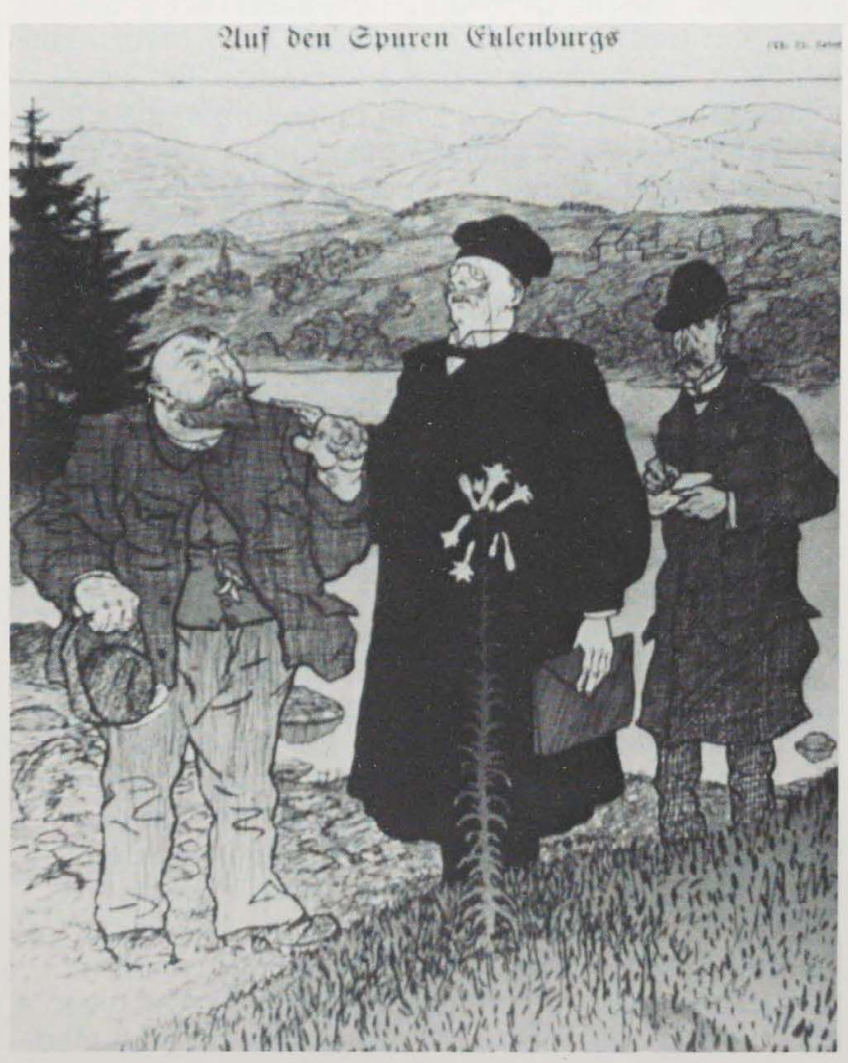

Figure 21 (caption above) On Eulenburg's Track. (caption below) "It was on this spot that the Prince first confessed his love to me!" From Simplicissimus (Munich), vol. 13, no. 10 (June 8, 1908), p. 165; original in color. 
The fifth major trial of the scandal was convened in Berlin on June 29, after Eulenburg had unsuccessfully sought a postponement due to ill health. The state prosecutor introduced as evidence incriminating books and correspondence confiscated at Liebenberg Castle, including one letter to Ernst written by Eulenburg prior to the Munich trial, urging him to reveal nothing. Ernst was, in fact, the prosecution's star witness, turning at one point to Eulenburg and ut tering in Bavarian dialect: "By God Almighty, Your Excellency, you can't deny that we two did it. Excellency, it's true. We two haven't got a chance in the world." "35 So enfeebled that he had to be carried into the court on a litter, Eulenburg continued to protest his innocence even when confronted with ten witnesses summoned by the prosecution-including three police officers, two former stewards on the royal yacht Hohenzollern, and a court servant who testified to having observed Eulenburg through a keyhole in $1887 .{ }^{36}$ The prosecution planned to call another thirty witnesses, but the defendant collapsed during a recess and was declared dangerously ill by medical attendants. Determined to press to a close, the judge resumed the trial on July 17 in Eulenburg's hospital. When the defendant passed out during the hearing, the judge relented and postponed further hearings until Eulenburg's health improved. Two months later he was provisionally released from the court's custody on posting a bond of 100 Marks and returned to his Liebenberg estate, where he was warmly received by his loyal tenants and gave interviews protesting his innocence.

Eulenburg's circulatory ailment enabled a broad sector of the German populace to accept the fact that the trial was repeatedly postponed - and ultimately never concluded. While they were convinced that the illness was feigned, even the socialists were not entirely displeased, since the Eulenburg case could serve as an object lesson in class justice only so long as he was not convicted. Most aristocrats and members of the middle class felt that Eulenburg had already been punished enough by his fall from grace; and indeed, he was never reaccepted into the kaiser's entourage. When he was audacious enough to vacation at a foreign spa, press grumblings led the judge to reconvene the trial on July 7,1909 , almost a year after the postponement. But when Eulenburg fainted one hour into the proceedings, he was given a conditional postponement: he was to undergo a medi$\mathrm{cal}$ examination at six-month intervals to determine whether he was fit to stand trial. This charade continued for a decade, after which the trial was indefinitely postponed. Eulenburg died in 1921.
The final trial of the scandal - the third between Moltke and Harden-received far less media attention than the earlier ones. It was originally scheduled for November of 1908 (the time of the Daily Telegraph affair) but was delayed until the following April. Harden was again convicted of libel and sentenced to pay a fine of 600 Marks plus court costs, which now amounted to 40,000 Marks. Unlike Eulenburg, Moltke was thus rehabilitated, and Harden continued to fret over the homosexual influence of Moltke and "the many other affiliates of the same caliber, who are still up there." ${ }^{37}$ As litigious as ever, he fully intended to appeal the verdict but allowed himself to be talked out of it by Chancellor Bülow, who argued that they had both achieved their goal by eliminating Eulenburg and that further trials dealing with homosexuality would be detrimental to the national interest. Harden was finally satisfied with a formal acknowledgment that he had acted out of "patriotic considerations" and a full reimbursement for his fines, secretly paid by the imperial chancellery. Fifteen years later, Harden acknowledged to Magnus Hirschfeld that initiating the Eulenburg Affair had been the greatest political mistake of his career ${ }^{38}$ He came to realize regretfully that Eulenburg had exercised a moderating influence on the kaiser and that his elimination had set Germany on a war course. And, although he never said so, Hirschfeld too may well have regarded his own involvement in the libel trials as the gravest misstep of his career. 


\section{Effects on the German Image}

Just a few days after the opening of the first trial in the three-year scandal, a leading Berlin daily described it as a "forensic drama claiming universal attention at home and abroad." 39 A month later, one Reichstag delegate asseverated that the courtroom revelations quite properly filled "the entire German people with revulsion and loathing" but noted with concern that "these matters, naturally blown up, are entering the foreign press and there producing extremely odd views about German morality and the future of Germany." 40 The Eulenburg Affair was thus a double crisis, damaging both national self-image and the international image of Germany; but while the former was subject to a certain amount of manipulation, the latter seemed exasperatingly beyond control. This concern was captured in one cartoon, "The Effect Abroad" (Figure 22). Here, two English tourists in Venice are struck by the appearance of a group of German women, and one concludes that their egregious homeliness is what drives German men to homosexuality. The thinly veiled misogyny of this cartoon points simultaneously to the thoroughgoing exclusion of women from the discourses of the scandal (the courtroom silencing of Lily von Elbe being the locus classicus) and to the attempt to find a scapegoat (be it Jews, homosexuals, or women) for the nation's im age problem.

While a comprehensive survey of the international reception of the scandal is beyond the scope of this essay, its outline can briefly be limned. Press coverage in the United States was quite extensive and ranged from the guarded reportage of the New York Times (see Katz 1983:322-323) to rank sensationalism in the era's yellow press. The French response was equally mixed but dealt with an additional dimension: Raymond Lecomte, counselor at the French embassy in Berlin, was a close friend of Eulenburg and was directly implicated in the scandal by Harden (see Figure 14). He claimed that as a result of a meeting between Lecomte and the kaiser at a Liebenberg shoot in 1906, the French went to the Algeciras Conference with the inside knowledge that Germany would not go to war with France over hegemony in Morocco. When Harden published his accusation, Lecomte - titled "king of the pederasts" (Tresckow 1922:168) — was recalled to Paris, but only to be rewarded with a post in another embassy. In light of ingrained Franco-Prussian hostility, it is scarcely surprising that some sectors of the French press gloated over Germany's embarrassment; homosexuality was in any case already called "le vice allemand" (Harden 1913:183, see also Blümner 1910:179-180). Paris cartoonists took special pleasure in lampooning the perverse esprit of "The Army Beyond the Rhine" (see Figures 23, 24, 25). Beneath the obvious Schadenfreude lurked the gleam of hope that the foe could

\section{Die Wirkung auf das Ausland}

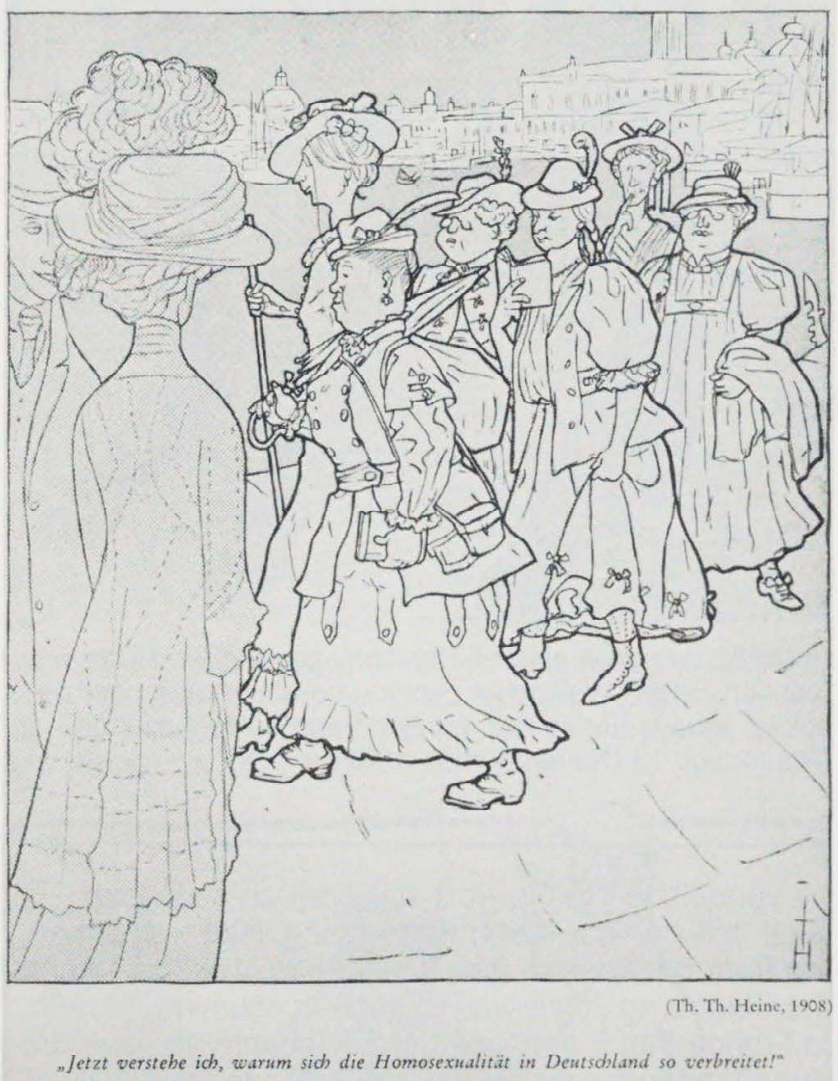

Figure 22 (caption above) The Effect Abroad. (caption below) "Now I understand why homosexuality is so widespread in Germany!" From Simplicissimus (Munich), vol. 13, no. 8 (May 25, 1908), p. 113; original in color. 


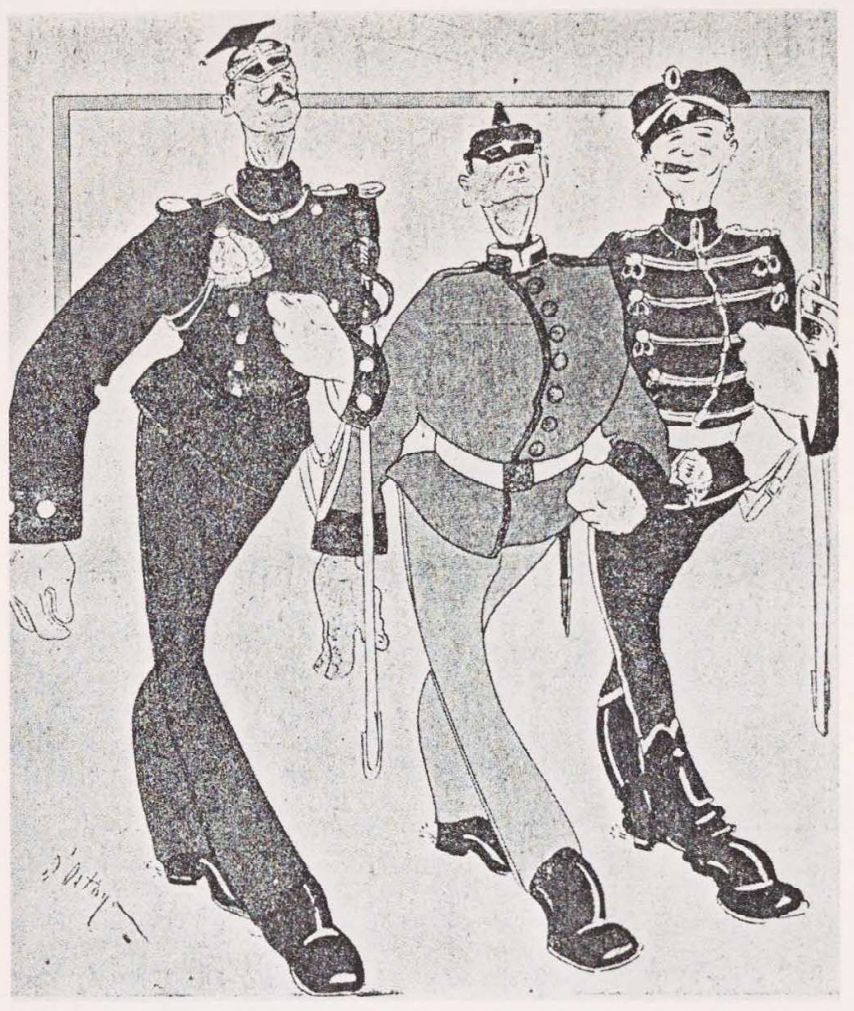

Figure 23 (caption above) The Army beyond the Rhine. (caption below) Well, what can you do about it? A poor soldier always has to risk his ass. From Le Rire rouge (Paris), vol. 13 (November 23, 1907).

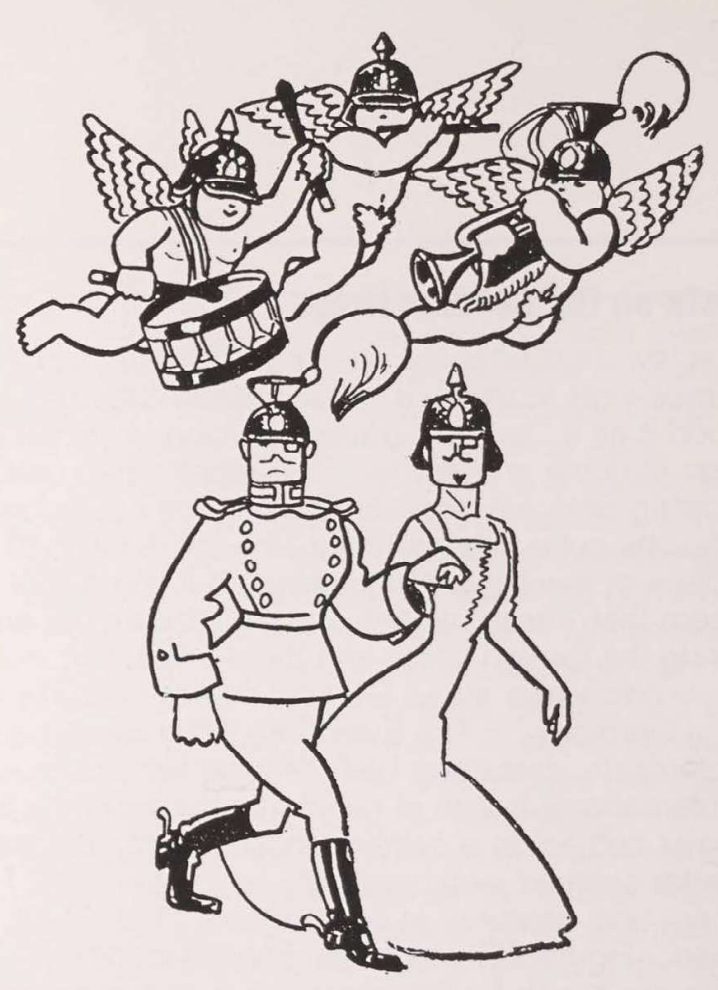

Figure 24 (caption below) Byzantium in Germany. From Fantasio (Paris), vol. 2 (November 15, 1907). be vanquished in the next war and, on a deeper level, the pervasive fear that France itself was suffering from decadence (see Nye 1982a, 1982b). Overall, the Eulenburg Affair was of such consuming interest to France that it remains the only country to have produced monographs on the subject (see especially Baumont 1933; Weindel and Fischer 1908; GrandCarteret 1908). Switzerland and Belgium tried to maintain their neutrality, but cartoons from these countries (Figures $7,9,11$ ) show the opprobrium they attached to homosexuality. In contrast, the Italian treatment tended more clearly to the sensational (see Figure 8).

Because they were yoked by a shared cultural heritage and an alliance that led to the Axis in World War I. Austria and Germany closely converged in their reactions to the scandal (see Figures 18, 19, 28, 29, $30,32,39,41)$. Still, the Austrian cartoonists enjoyed greater freedom in linking the kaiser with the scandal, and pictorial anti-Semitism was more openly aggressive in Vienna than in Berlin (see Figure 5). The British response was initially quite restrained and even tactful; but, as the enmity between the countries grew, various English publicists demonstrated that the scandal was by no means forgotten. In the final year of World War I, the English "libel case of the century" began with the remarkable assertion that Germany was ruled by a homosexual clique whose secret agents had debauched thousands of English men and women who now obeyed orders from Potsdam (see Kettle 1977:4-12; cf. also Igra 1945). The
Eulenburg Affair was recalled during the war not just in Britain: cartoons in both France and Italy revived motifs from the era of the scandal, portraying the German army as perversely effeminate and thus easily defeated. ${ }^{41}$ Yet the memory persisted longer at home than abroad: in the early 1930s, antifascist German cartoonists once again used the selfsame images to attack Ernst Röhm's SA, and both Hirschfeld and Hitler himself remarked on the historical parallel. ${ }^{42}$ Fascists tended to perpetuate the anti-Semitic interpretation of the Eulenburg Affair and held up Harden and Hirschfeld as prime examples of the Jewish conspiracy against German morals (see Institut zum Studium der Judenfrage 1936:371-373; Frank 1942).

Hitler's recollection of the scandal is indicative of the abiding damage it inflicted on the German selfimage. Harden's voice was only one in a chorus that harped on the theme of "national disgrace" (Harden 1913:248), an outlook that also found frequent pictorial expression. Cartoonists employed a variety of symbolic figures to invoke the nation. The one female representative was Germania (Figures 3 and 7), tellingly portrayed doing women's work - sweeping and washing - to cleanse the homeland. The nation's other avatars were all men and included the German Michel in his sleeping cap (see Figure 13), the hero Siegfried, Germany's legendary dragonslayer (see Figure 16), and the medieval Kaiser Barbarossa (see Figure 26), of whom legend said that he had not died but instead slept in a mountain fastness encircled by 
ravens, whose departure would awaken him to do battle in the hour of Germany's greatest need. In addition to these mythical and allegorical figures, cartoonists also invoked historical figures to represent the nation. An amusing example is the statue of Goethe and Schiller in Weimar (see Figure 20). A statue of Hermann, the Germanic leader whose warriors defeated three Roman legions in the year A.D. 9, figures similarly in another cartoon not reproduced here. In both cases Hirschfeld is shown questioning the normalcy of these historical giants; and, indeed, articles published by Hirschfeld did explore the homosexual aspect of the writings of Goethe and Schiller. ${ }^{43}$

The most striking feature shared by these male na tional symbols is their apparent ineffectualness in the face of a moral transformation they can scarcely begin to comprehend. Germania alone rolls up her sleeves and resolutely sets about cleaning up the mess, whereas the men all embody one variant or another of powerlessness. Be it the German Michel timorously examining a dragon that may not be dead, the dragonslayer Siegfried belonging to an heroic past now irretrievably lost, Barbarossa still recumbent in his rocky redoubt, or Goethe and Schiller frozen in their statuesque but compromising embrace, these national symbols evoke a proud cultural heritage now perceived as crumbling under the onslaught of modernity. Not just in Germany but also in France and England, contemporaries experienced the era of the turn of the century as under assault by the accelerating tempo of change, and the rush of time brought in its wake new diseases of civilization: bad nerves, homosexuality, and degeneracy of all sorts (see Mosse 1982:229-230; Schivelbusch 1979:118-121). The agitated nervosity of the modern age was captured in the cartoon image of Hirschfeld actually running to the Weimar statue.

In an article entitled "Who Is to Blame?" Hirschfeld argued that the sensational publicity surrounding the Eulenburg Affair had given rise to three related but distinct misconceptions. First, he rejected the notion that "degeneration, a process of decay" was more extensive in Germany than in other nations (Hirschfeld 1907c:1522). This welcome assurance was widely echoed, often in a stridently xenophobic tone, by newspaper editorialists, Reichstag speakers, and the like. ${ }^{44}$ Second, he described as mistaken the impression that homosexuality was more prevalent among the aristocracy than among commoners. While upperand middle-class apologists for the status quo ac cepted and repeated this assertion, it did not find universal acceptance. Some members of the educated middle class suggested that centuries of intermarriage among German blue bloods had resulted in hereditary degeneracy, of which homosexuality was one manifestation (see, e.g., Tresckow 1922:111-112), while others - including various middle- and workingclass cartoonists - saw it simply as the latest variation on an age-old theme: the aristocracy's sexual license, at once despised and envied (see Figures 18 and 27). And third, Hirschfeld claimed that, contrary to popular belief, homosexuality was no more widespread in the present than it had been in the past. With this thesis he stood virtually alone

A disturbing increase in the rate of "unnatural crimes" had been noted by cultural critics as early as the $1880 s^{45}$ and by 1908 one alarmed editorialist asserted that the continued spread of homosexuality threatened the German race with extinction. ${ }^{46}$ The Eulenburg Affair prompted Adolf Stöcker, court chaplain under Kaiser Wilhelm I and now the foremost anti Semitic politician in the Reichstag, to argue that the

Figure 25 (caption below) We don't want no antimilitarists here! We hold the firm seat of our soldiers' order and morality in respect. From L'Assiette au beurre (Paris), no. 346 (November 16, 1907).

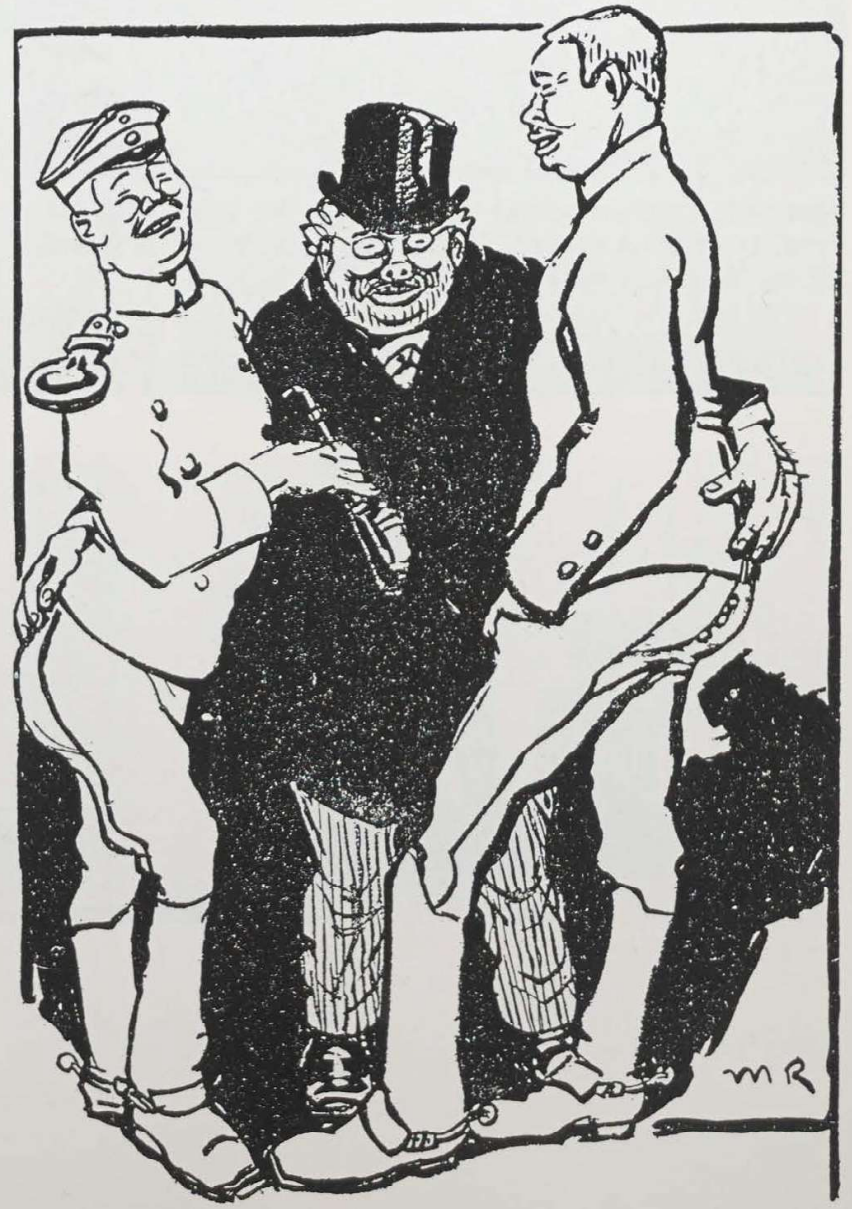




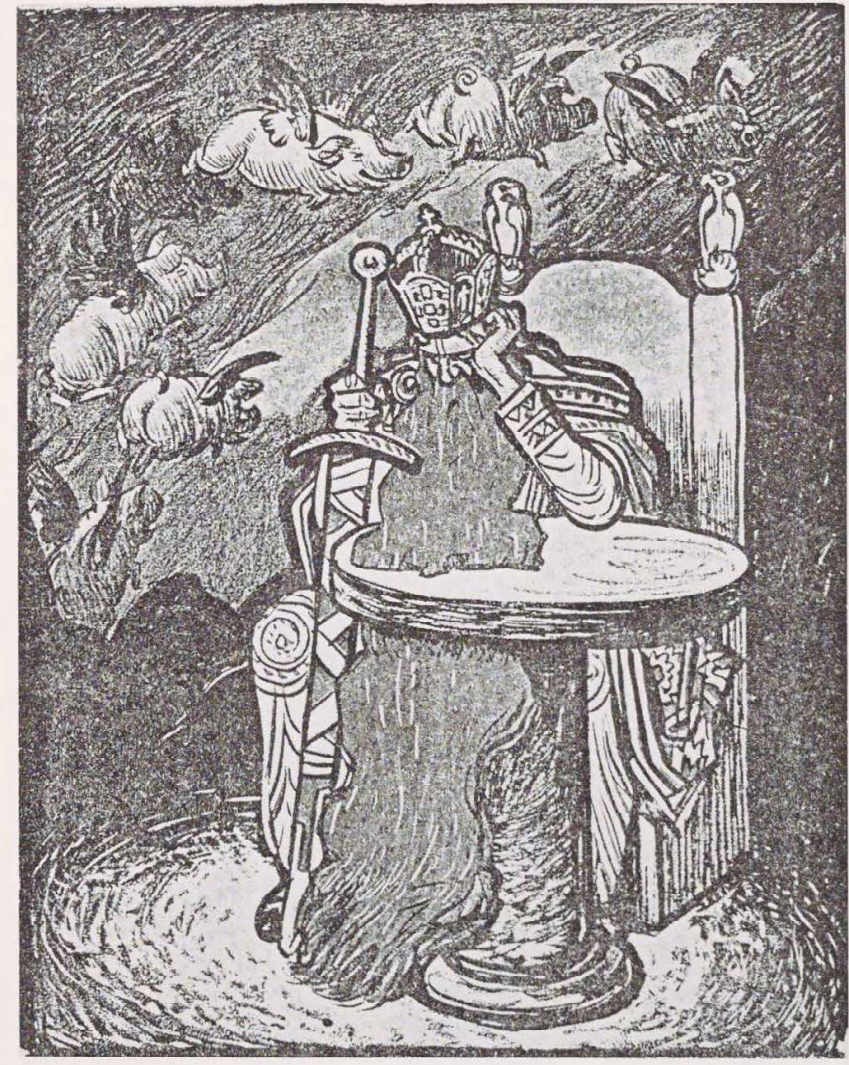

Figure 26 (caption below) Barbarossa: "Are the ravens still flying around the tower?" From Lustige Blätter (Berlin), vol. 22, no. 45 (November 5, 1907), p. 3.

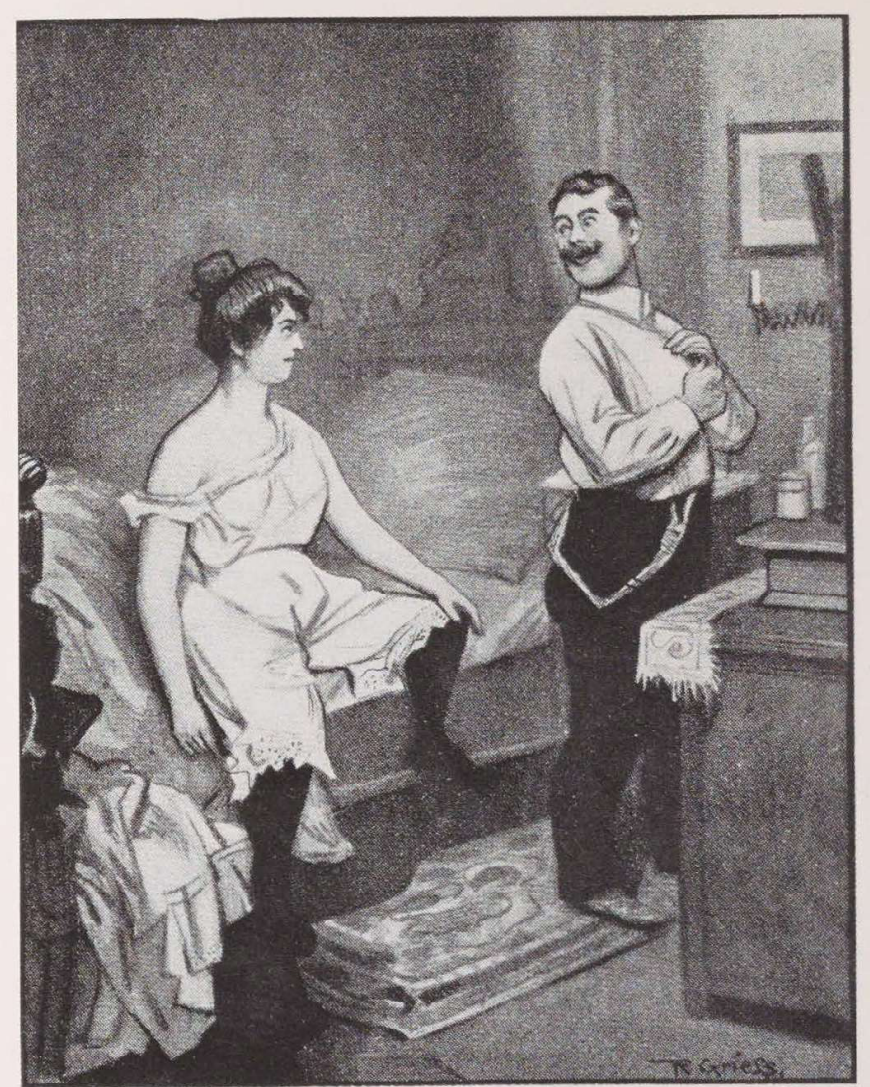

2Ad), Dstar, bu bift ood) mur cin gewöhnlidfer Flebejer - gar nicft ein biß̧⿻)丨en homoiezuell!"

Figure 27 (caption above) Disappointed. (caption below) "Oh, Oscar, you're just an ordinary plebian - not even the least bit homosexual!" From Der wahre Jacob (Stuttgart), no. 560 (January 7, 1908), p. 5683.

Figure 28 (caption above) Sensation in the Café Moderne. (caption below) A married couple is coming! From Wiener Caricaturen (Vienna), vol. 27, no. 44 (November 3, 1907), p. 4.

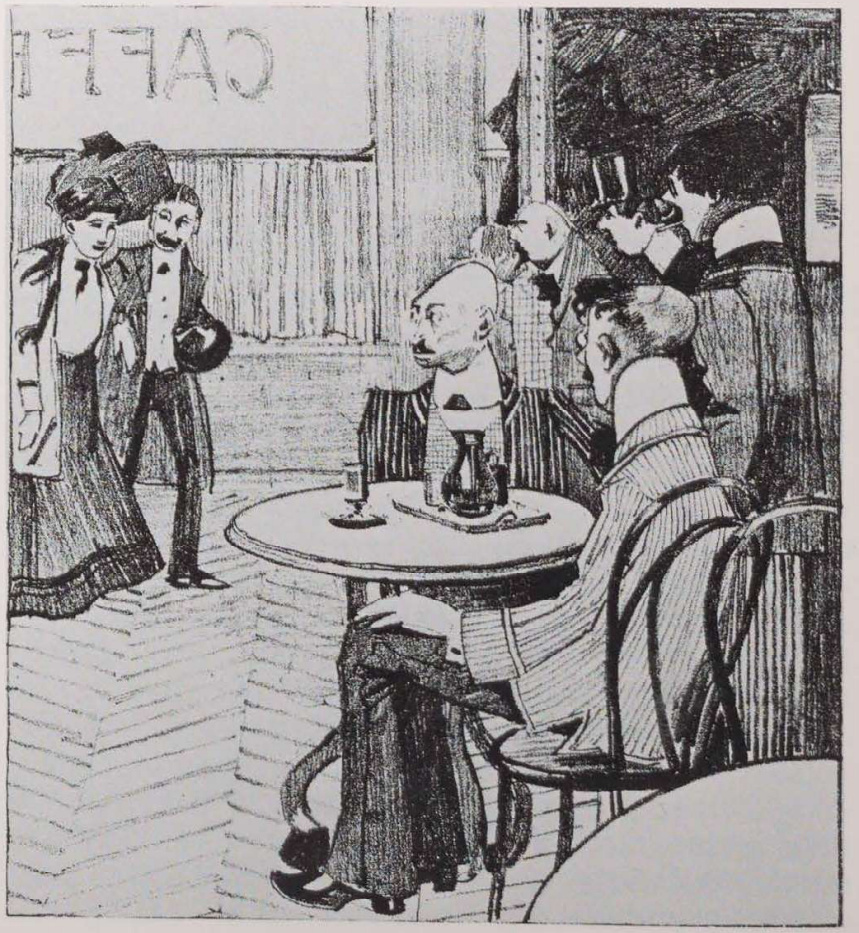


Figure 30 (caption above) Changes in Prussia Over the Past 100 Years. (caption below) Marshall Forward and General Backwards! From Wiener Caricaturen (Vienna), vol. 27, no. 44 (November 3 , 1907), p. 12.
Figure 29 (caption below) Then and Now. From Der Floh (Vienna), undated special issue on Paragraph 175 (ca. November 1907), p. 4.
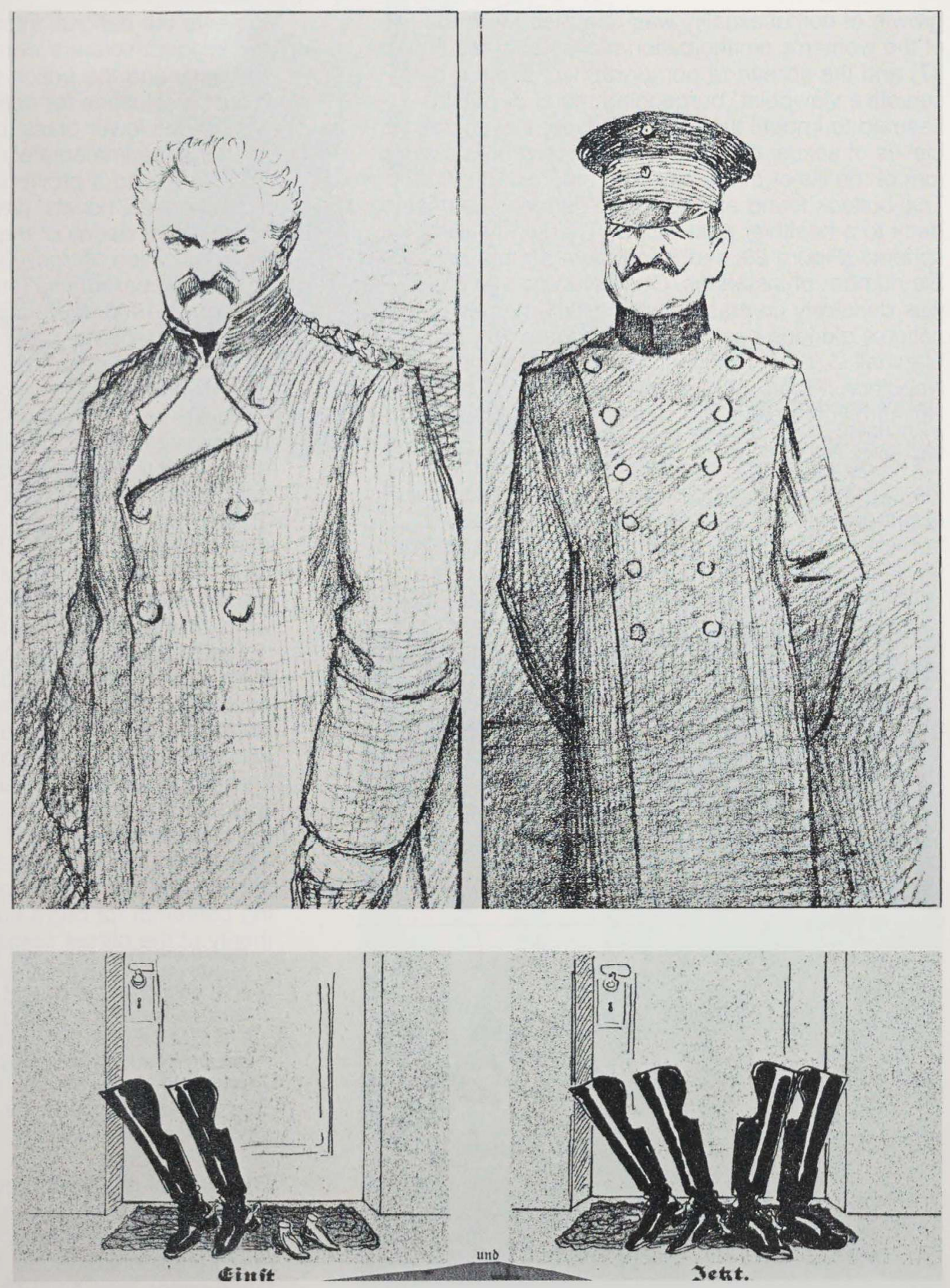
growth of homosexuality was of a piece with the rise of the women's emancipation movement (see Figure 37 ) and the spread of pornography. ${ }^{47}$ From a conservative viewpoint, burgeoning moral depravity seemed to imperil the very foundations of society: enclaves of sexual deviates were perceived as a symptom of the ills of modernity (see Figures 18, 28, 35). This outlook found expression in cartoons hearkening back to a healthier past with a "Then and Now" schema (Figure 29; see also Figure 5). In a remarkable number of instances, General Kuno von Moltke was derisively contrasted with military heroes of the nation's glorious past: Siegfried (Figure 16); Field Marshall G. L. von Blücher, who had vanquished Napoleon (Figure 30); and his namesake, General Helmuth von Moltke, the victorious commander in the Franco-Prussian War of 1870 (Figure 31).

The overwhelming prevalence of military themes in the cartoons mirrors both the imperial preoccupations of the era and the concern that the army was extremely susceptible to corruption. Officers quite routinely subjected enlisted men to extreme abuse of various sorts. Extended into the sexual sphere, however, abuse not only undermined the status of rank but also sexualized the military, thus violating a major taboo (see Figures 32 and 33). Soldiers functioned as a particular variant of the national symbol, and although their uniforms were actually designed with aesthetic criteria in mind-and thus fostered fetishization as disembodied male power-the stereotype of the soldier was supposed to transcend sexuality by submitting aggressiveness to discipline, reshaping it

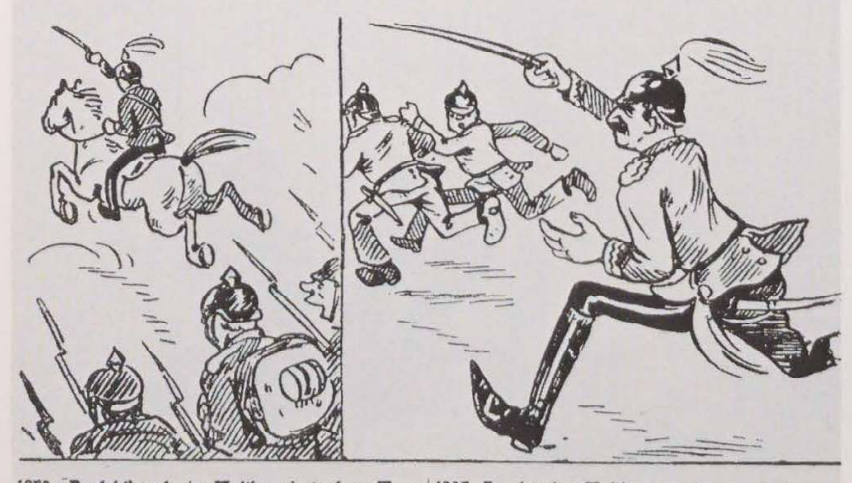
1870: "Da lebr' noch der Molthe, ein tapferer Mann, 1907: Der heutige Molthe, man hat es gehört,
Der griff die Soldaten von vorne an.

Figure 31 Postcard from the scandal era, with a caption in doggerel. 1870: Moltke lived then, a truly brave man; he always attacked head-on. 1907: Today's Moltke, from what we hear, always attacks - from the "rear"! From Linsert (1931: facing p. 474). to serve the national interest (cf. Hull 1982b:297). ${ }^{48}$ In this respect soldiers were not unlike criminals, and the army and the prison were perhaps the two paramount institutions for controlling and regulating the lives of the lower class (cf. Foucault 1980:17).

The years immediately prior to the Eulenburg Affair had witnessed a proliferation of discourses-journalistic exposés, novels, plays, autobiographies - suggesting that decay of the officers' code of honor and demoralization of troop discipline were undermining military preparedness (see, e.g., Bilse 1904;

Hartleben 1900; Beyerlein 1914, 1915). Still, none of this had adequately prepared the nation for Harden's assertion that "entire cavalry regiments [were] infested with homosexuality. "49 Various Reichstag speakers rose to defend the spirit of Potsdam, but their confidence in the army was shaken by Harden's disclosure that uniformed soldiers were flagrantly prostituting themselves in certain areas of Berlin, ${ }^{50}$ including the promenades of the Tiergarten (clearly discernable in Figure 19). The gravity of the situation was finally brought home when Harden revealed that the minister of police himself had been accosted while taking an evening stroll (see Figure 34).

The barrage of charges reached such intensity that the minister of war, General Karl von Einem, was compelled to deliver a rambling report to the Reichstag in which he variously asserted that there was no problem, that a problem did exist but was entirely attributable to civilian "rascals" (see Figure 19), and that the problem would be resolved by heightening disciplinary control. ${ }^{51}$ Any officer guilty of homo sexual conduct, he argued, dishonored himself and thereby forfeited the respect of his troops; the resulting contempt for one's superior undermined the authority of the officer corps:

That cannot and must not be. If such a man with such feelings should be lurking in the army, I command him: Resign your commission, get out, for you do not belong in our ranks! [Bravo!] If, however, he should be caught, then, gentlemen, regardless of who he may be, regardless of his post, he must be destroyed. [Bravo!] [Germany 1908a:1916]

The trials of the Eulenburg Affair were indeed conducted against a somber tattoo of resignations, suicides, and courts-martial. Ironically, as Hirschfeld noted (Hirschfeld 1908d:1-3), the publicity given these cases may have done more to erode than to restore the honor code and discipline for which the officer corps had traditionally been respected-and feared. 


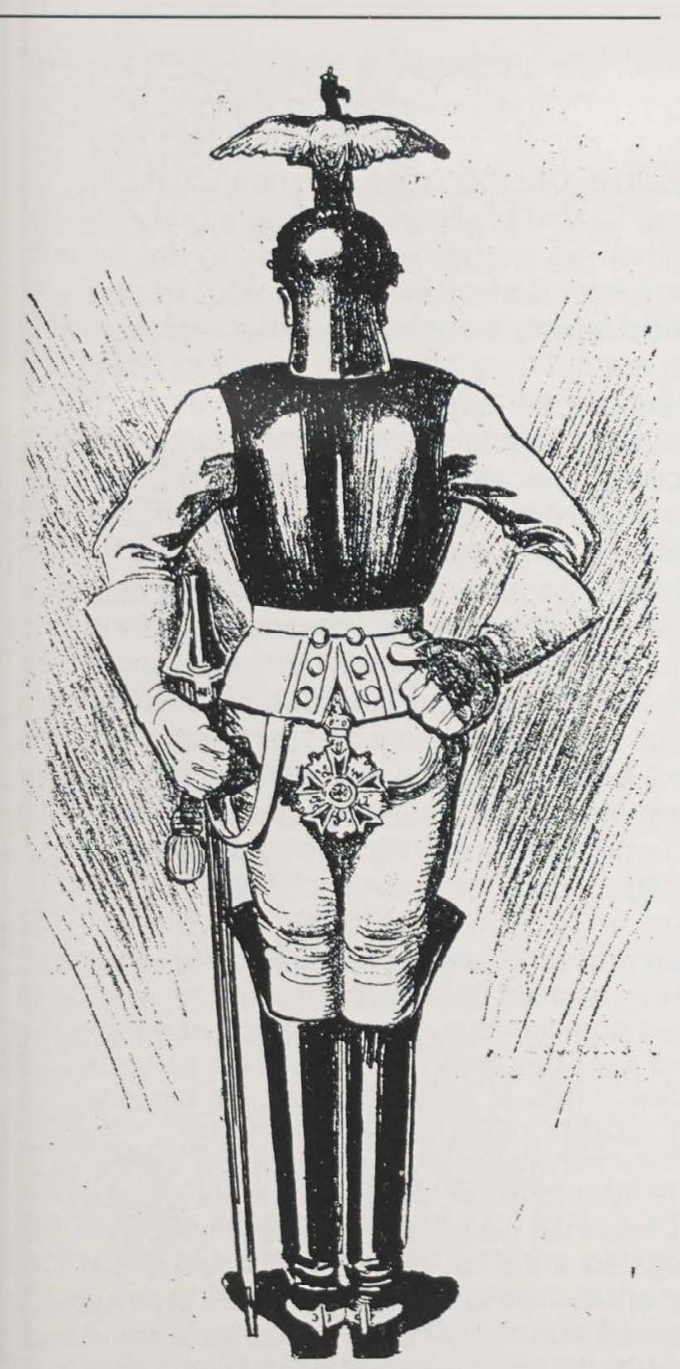

Figure 32 (caption below) As we hear, the Prussian medal pour le mérite is to be worn thus in the future. From Neue Glühlichter (Vienna), vol. 10, no. 304.24 (November 20, 1907), p. [4].

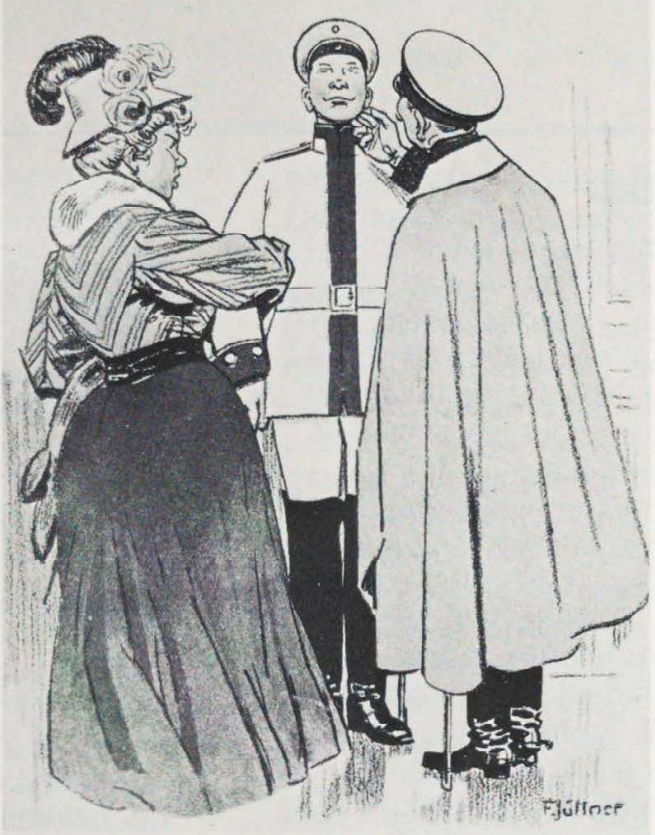

Die eifersuchrige Rieke.

da tas ick mir nich on

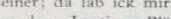

Figure 33 (caption above) Jealous Marie. (caption below) "No, he's mine; get your hands off!" From Lustige Blätter (Berlin) vol. 22, no. 45 (November 5, 1907), p. 12.

Pad)tleben in Potgban.

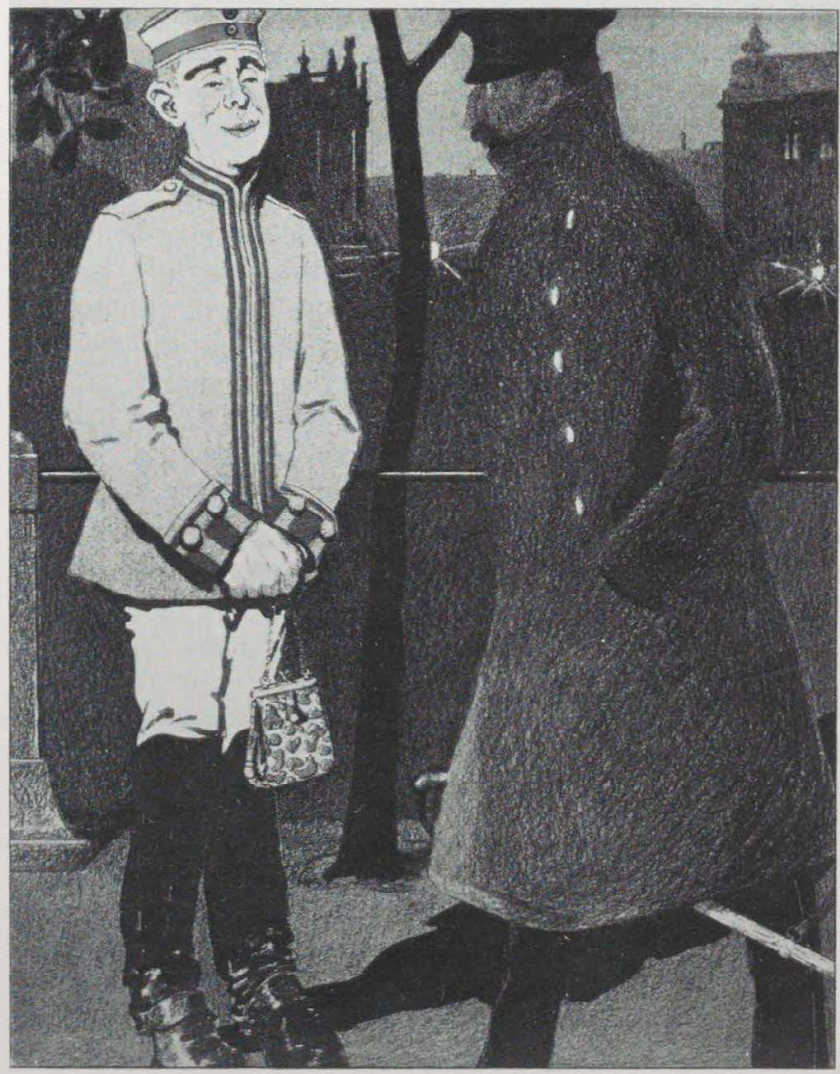

Figure 34 (caption above) Nightlife in Potsdam. (caption below) "Say, big fellow, want to come along?" From Der wahre Jacob (Stuttgart), no. 557 (November 26, 1907), p. 5616 ; original in color. 


\section{Sexual Practices and Identities}

Just what sort of men did the minister of war want removed from the officer corps? The answer was not nearly so straightforward as it might at first secm, for a satisfactory definition of sexual normalcy and abnormalcy was still evolving (Mosse 1982:221-246; Hull 1982a:247-268). Harden might thunder in court, "Let us draw a clear line between men like Eulenburg, Hohenau, Moltke and the men of Germany!" but the precise border seemed elusive to many. ${ }^{52}$ The scandal contributed enormously to legitimating the embryonic discipline of sexology (cf. Stöcker 1908:285 288), which accounts for the grudging respect accorded Dr. Hirschfeld; not coincidentally, he founded the Journal of Sexology in 1908. As he noted, the very word "homosexuality" was either lacking in standard dictionaries or was hastily included in the latest editions; it had been coined in 1869 and, until the Eulenburg Affair, belonged exclusively to the parlance of forensic medicine. Throughout the trials, he complained, the term was continually confused with "pederasty" (which entailed two taboos, samesex and transgenerational relations), "unnatural vice" (the acts criminalized by Paragraph 175), and a host of pungent colloquialisms (Hirschfeld 1908d:1-3).

In the first trial of the scandal, it will be recalled, Hirschfeld had argued - and the judge had agreed that Moltke was neither a pederast nor a felon but instead a homosexual, i.e., an effeminate man, a person who confounded sex-role stereotypes by virtue of his emotionality, passivity, artistic temperament, emotional attachment to men, and so on. By demonstrating the existence of a sexual deviance that did not necessarily find expression in sexual behavior, Hirschfeld naively hoped to advance the cause of enlightened tolerance, but the court's verdict had precisely the opposite effect. While the distinction between homosexuality and heterosexuality was new and arcane, a clear boundary between masculinity and femininity had been established in the nineteenth century, and public consternation over the violation of the latter norm was far more severe than Hirschfeld had anticipated. In an era that was obsessed with the imperialist projection of such masculine traits as strength, courage, hardness, and military aggressiveness, the violation or nonviolation of Paragraph 175 became a secondary concern, while homosexuality understood as male effeminacy-became a potent metaphor in political discourse (cf. Hull 1982b:133-136, 145, 296-297). This, of course, is why Harden had been able to exploit the issue in the first place, and why he produced evidence of Eulenburg's misconduct only when his hand was forced. Harden's final revelations rendered moot the distinction, so painstakingly constructed by Hirschfeld, between sexual orientation and conduct.
The dispassionate discourse of a sexological expert was drowned out by the saber-rattling rhetoric of sexual politics on a grander scale than Hirschfeld had imagined possible, but this does not mean that his standpoint was flawed or illogical-simply that more was at stake than an academic question. In the rather abstruse sense intended by Hirschfeld, Moltke and Eulenburg undoubtedly were homosexual and would have been so even if they had been totally sexually abstinent. In private correspondence, Eulenburg described himself as combining "feminine feeling with masculine activity"; he was proud, perhaps inordinately so, of his artistic "sensibility and finer organization," precisely the traits that appealed to Kaiser Wilhelm. ${ }^{53}$ Moltke, too, was characterized by a close friend as deficient in the "dash," "masculinity," and "toughness" of the kaiser's other military advisers, ${ }^{54}$ but neither he nor Eulenburg thought of himself as a homosexual. In a remarkably candid and revealing letter to Moltke (July 10, 1907), written prior to the first trial, Eulenburg struggled to defend his admittedly old-fashioned conception of their affinity against the new-fangled label:

At the moment when the freshest example of the modern age, a Harden, criticized our nature, stripped our ideal friendship, laid bare the form of our thinking and feeling which we had justifiably regarded all our lives as something obvious and natural, in that moment, the modern age, laughing cold-bloodedly, broke our necks.... The new concepts of sensuality and love stamp our nature as weak, even unhealthily weak. And yet we were also sensual, not any less than the moderns. But this area lay strictly segregated; it did not impose itself as an end in itself. Family, art, friendship, and all our ideals were completely divorced from sensuality and from that which we regarded only as dirt, even if it might have ruled us here or there in those unconscious reciprocal effects which characterize "mankind." [quoted in Hull 1982c:199]

It would be all too pat to interpret the terms "ideal friendship" or "art" as mere euphemisms for homosexuality; in fact, the code word here is "dirt." This letter suggests that these two aristocrats - and others of their estate - made a clean break between homosexual and what might be termed homosocial relations, strictly confining the former to contacts with members of the lower class and cultivating the latter with like-minded peers. They did not identify themselves as homosexuals because their occasional sexual escapades played at most a subordinate role in their lives.

When Eulenburg, trained as a lawyer, knowingly perjured himself by swearing that he had never violated Paragraph 175, he may have assuaged his conscience by reasoning that only relations in high society were at issue, and here he was no more and no less than a devoted father, husband, and friend. He was not dissembling when he swore in court: ${ }^{55}$ 
In my youth I was an enthusiastic friend. I am proud of having had good friends. ... The best thing we Germans have is friendship, and loyal friendship has always stood in high regard. I have had enthusiastic friendships, I have written letters that overflow with enthusiastic feelings, and I don't reproach myself for it at all. Surely we know the letters of our great heroes, Goethe and so on, which are effusive. I have certainly written such letters too, but there was never anything wicked, evil, filthy in them.

When Hirschfeld remarked that the language of Goethe's era was no longer appropriate "in our technical and military age," ${ }^{156}$ Eulenburg once again defended his ideal vision of friendship against sexual inferences in emphatic terms: "This is a slam at German friendship, it's a poison that's being trickled into friendship, no one is safe, that is a betrayal of Germany!" (quoted in Hirschfeld 1908d:24). And, indeed, Hirschfeld may have underestimated the extent to which forms of expression regarded as outmoded by the middle class were perpetuated by the aristocracy, whose very station in life derived from and was legitimated by tradition.

If class distinctions were so central in Eulenburg's life that they allowed him to trivialize his felonies as mere peccadilloes and to resist the homosexual label, they likewise allowed Jakob Ernst to regard his extramarital intimacies as a separate sphere that did not impinge on his identity as a God-fearing, Bavarian family man-blessed with good fortune, thanks to the generous prince. Harden's researches revealed that Ernst's liaison with Eulenburg was common knowledge in the village of Starnberg. Ernst had long been so proud of his association with the prince that he bragged of it to his neighbors, who appear to have been more awed than outraged: no one had ever brought the affair to the attention of the district attorney. Ernst's court confession was highly revealing:

If I have to say it: what people say is true. What it's called I don't know. He taught it to me. Having fun. Fooling around. I don't know of no real name for it. When we went rowing we just did it in the boat. He started it. How would I have ever dared! With such a fine gentleman! And I didn't know anything about it. First he asked me if I had a girlfriend. Then it went on from there. [Harden 1913:258]

It proved easier to extract a confession from Ernst than from Eulenburg, for the simple farmer was eager to oblige the court-just as he had proved willing to oblige "a fine gentleman." And, unlike the prince, he had never cultivated a secret life.

Homosexual relations with the lower orders may have been regarded by the noblemen involved as an "obvious and natural" prerogative, but this outlook was anathema to the middle class, which - as Foucault has noted-supplanted the aristocratic focus on blood with the bourgeois focus on sex, ge- nealogy with morality (Foucault 1978:124). The German bourgeoisie had touted its moral superiority to the frivolity and cavalier licentiousness of the aris tocracy beginning in the eighteenth century, and during the nineteenth it extended its condemnation to the moral turpitude of the proletariat. ${ }^{57}$ By exposing sexual liaisons between officers and enlisted men, a prince and a farmer, middle-class journalists suggested that two of the three pillars of society were shot through with moral rot and could precipitate national collapse. ${ }^{58}$ One liberal, middle-class delegate to the Reichstag proclaimed the scandal a portent of a relapse into barbarism; homosexuality was a contagion that could attain epidemic proportions and wipe out culture. ${ }^{59}$ His relatively enlightened standpoint was evident in his use of the medical model, describing homosexuality as a sickness rather than a sin (see Bullough 1976:161-172).

If homosexuality came to be regarded as perilous because it crossed class lines, it also came to be seen as traitorous because it crossed national frontiers. Eulenburg's French connection confirmed for Harden Bismarck's dire warning that the cinaedi constituted an international association in much the same way as the socialists - those "fellows without a fatherland." The homosexuals' secret "lodge," Harden asserted, was stronger than freemasonry and leaped over "the walls of creed, nation, and class" to create a "fraternity" that sneeringly regarded "normals as a lower form of life.... It is a different world than ours, with a different moral code, a different set of values." Since homosexuals regarded heterosexuals as "the common enemy" and were seeking "gradually [to] emasculate our courageous master race before the nation notices what is happening," Harden called for a "fight to the death" with this "powerful group." Eulenburg seemed to personify the danger: he was "the amoureuse who has toyed with scepters and thrashed in lustful ecstasy on the sweaty sheets of his coachman" (Harden 1913:182-183, 244, 248, 278). ${ }^{60}$

Harden's mordant attacks on Eulenburg are particularly noteworthy because they signaled a complete about-face. In 1898, Harden had become the first German editor to support the campaign for homosexual emancipation led by Hirscheld. Articles by Harden, Hirschfeld, and others in Die Zukunft had called for the repeal of Paragraph 175 and for greater tolerance toward these "martyrs of a misguided sexual drive" who deserved "neither punishment nor contempt" (Harden 1905:314). He claimed that the flood of hate mail he had received during the Eulenburg Affair from homosexuals in all walks of life had convinced him that this tolerance was entirely misplaced, and his change of outlook matched a broader shift in middle-class attitudes toward homosexuality and sexuality in general. At the beginning of the scandal, 
Hirschfeld noted with dismay that the most vehement spokesmen of "the antihomosexual movement" came precisely from "the educated middle class" (Hirschfeld 1908d:6), and he thanked the German working class and the socialist delegates in the Reichstag for their continued support of the campaign to repeal Paragraph 175. By the scandal's end, however, the "psychic epidemic" of homophobia had spread even to the far left (Hirschfeld 1907d:242; 1909:20). It remained for the right-wing fanatic, Dr. Wilhelm Hentschel, to proclaim that the Eulenburg Affair had been beneficial if it had driven homosexuals to poverty and to suicide, and to describe the extermination of all homosexuals a desideratum of German society (Hentschel, 1909:93).

The scandal not only scuttled the campaign to repeal Paragraph 175, but led to far harsher enforcement of the law and efforts to strengthen and extend it. ${ }^{61}$ Whereas the existing statute punished homosexual acts only between men, a motion introduced by the Catholic Center party sought to align Paragraph 175 with the corresponding Austrian law, which included lesbians (see Figure 35) (see Kokula

Figure 35 (caption above) Spring Excursion of a Berlin Ladies' Club. (caption below) "Never, my sweet, will a man break up our love." "Never, dearheart!-Unless it's a policeman." From Simplicissimus (Munich), vol. 14, no. 7 (May 17, 1909), p. 106; original in color.

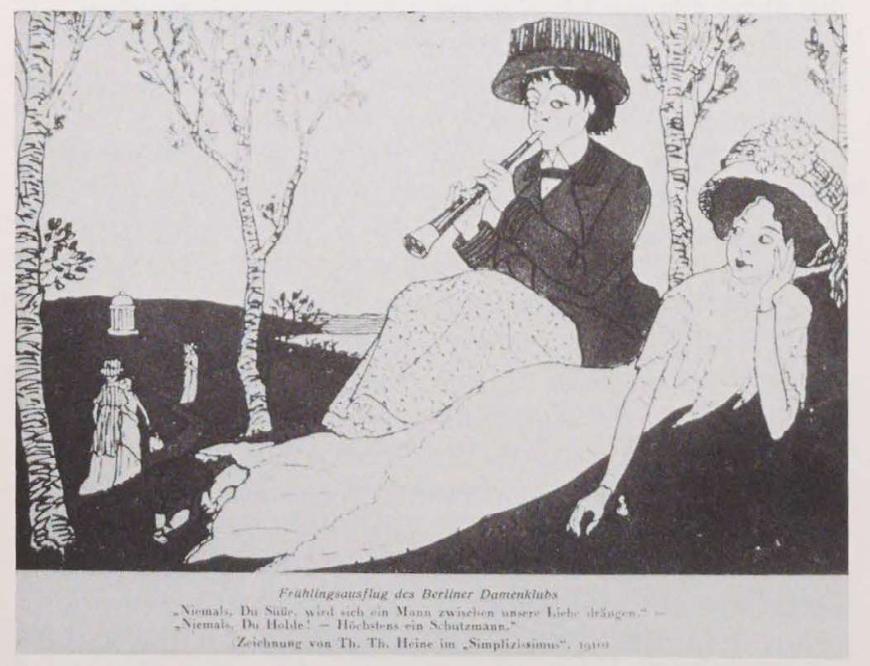

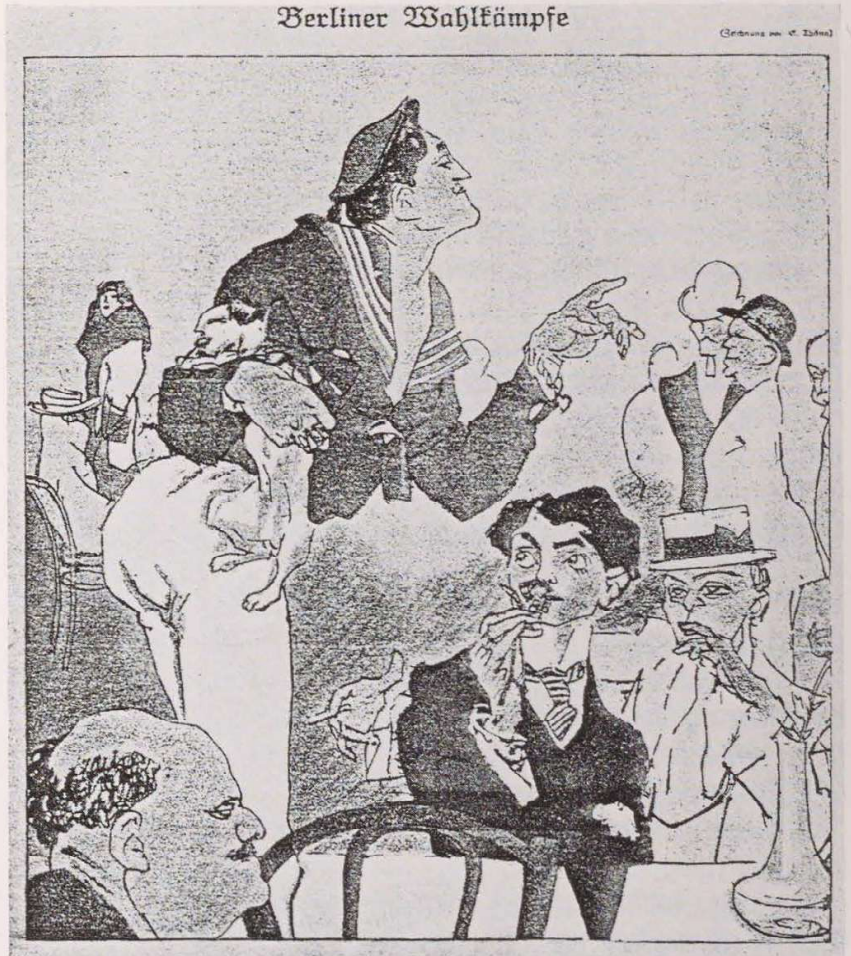

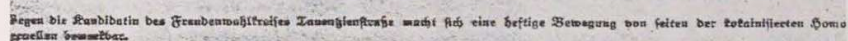

Figure 36 (caption above) Berlin Election Campaign.

(caption below) A hotly contested race is taking shape in the red-light district around Tautzienstrasse, where the woman candidate is being challenged by agitators in the cocaineinfested homosexual bars. From Simplicissimus; here reproduced from Linsert (1931: facing p. 152).

1981:30-31, 248ff). With the imprisonment of Adolf Brand and the discrediting of Hirschfeld as a "monomaniac" who was lucky "not to be tarred and feathered" (Hirschfeld 1907d:231; 1908b: 650-651), the homosexual emancipation movement entered a period of enforced quiescence from which it would not recover until after the kaiser's abdication in 1918. The women's movement was also profoundly affected by the moral purity campaign advanced with evangelical fervor in the wake of the Eulenburg Affair. In 1908, a change of leadership in the League of German Women's Organizations replaced its progressive program of sexual self-determination with a racist and nationalist interpretation of women's sexuality that sought to increase the German birthrate (see Evans 1976:156). Those few homosexuals and feminists who continued to agitate for sexual emancipation were mocked in strikingly similar imagery (see Figures 36 and 37). 
Peue 3iele in ber Framenbenegung

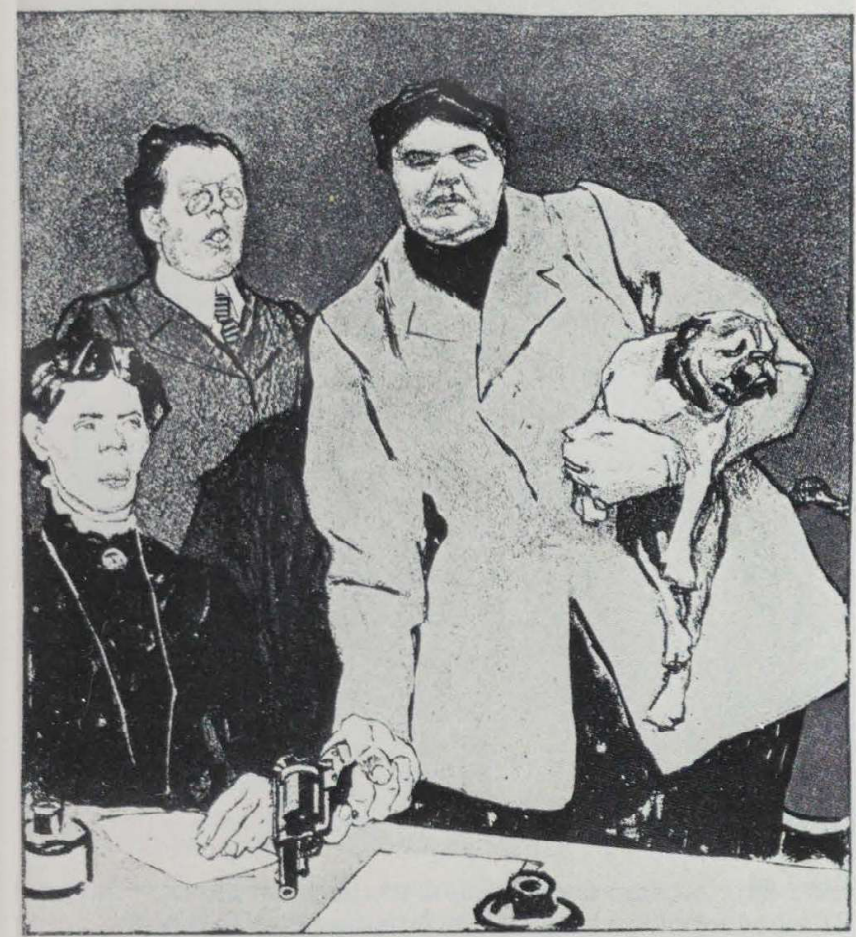

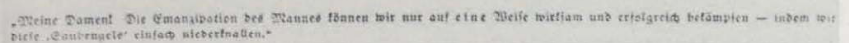

Figure 37 (caption above) New Goals in the Women's Movement. (caption below) "Ladies! We can struggle effectively and successfully against the emancipation of men in one way only: by simply gunning the bastards down." From Simplicissimus (Munich), vol. 15, no. 46 (February 3 , 1911), p. 765; original in color.

Repugnance at the inversion of traditional sex roles was particularly evident in the frequent use of animal and excremertal metaphors for homosexuality in both the discourses and the cartoons occasioned by the scandal. This radically dehumanizing rhetoric reached a high point when one liberal Reichstag delegate, Dr Siegfried Heckscher, declared that "homosexuality is dog morality," a slogan that was universally quoted and elaborated upon in the German press (see note 59). Eulenburg himself added ammunition to the antihomosexual arsenal when he swore that he had never engaged in "swinish" or "filthy" conduct, ${ }^{62}$ but the impetus had actually been given on the first day of the first trial, when Lily von Elbe offered the shocking testimony that her ex-husband had called women "toilets" and termed marriage "a swinish institution."63 Outraged, the virtually universal defenders of womanhood and family life responded in kind, and even the restrained Vossische Zeitung, the Berlin newspaper of record, rose to the occasion by coining the epithet "cloaca maxima" for Hirschfeld, slyly parodying the sexologist's Latinate neologisms. ${ }^{64}$
Dozens of cartoons employed dogs (see Figure 15), pigs (see Figures 8, 26), and excrement (see Figures $3,8,9,15)$, and an unusual degree of inventiveness must be granted to the artist who actually depicted a Schweinehund (pig-dog), the beast often invoked but never seen in German-speaking lands (see Figure 11). Such a monster would obviously have to be the offspring of an unnatural pairing, and this too was portrayed (see Figure 38). The use of animal and excremental motifs was by no means limited to German cartoons: one from France features a pigfaced man (see Figure 25), effectively completing the transformation of human into subhuman. While well known in the history of racism, this phenomenon has an additional dimension in connection with homosexuality: the term "sodomy" has comprised both bestiality and homosexuality throughout the history of Christian Europe. During the Middle Ages and Renaissance, sodomy was further so closely linked with heresy and witchcraft that at times the terms were virtually synonymous; by equating homosexuality with treason, Harden was merely updating this legacy (see Bray 1982:19-21). These animal images are in-

Figure 38 (caption above) Head to Head. (caption below) "My sweetheart, my loverboy, my one and only cuddlybear." From Lustige Blätter (Berlin), vol. 22, no. 45 (November 5, 1907), p. 9.

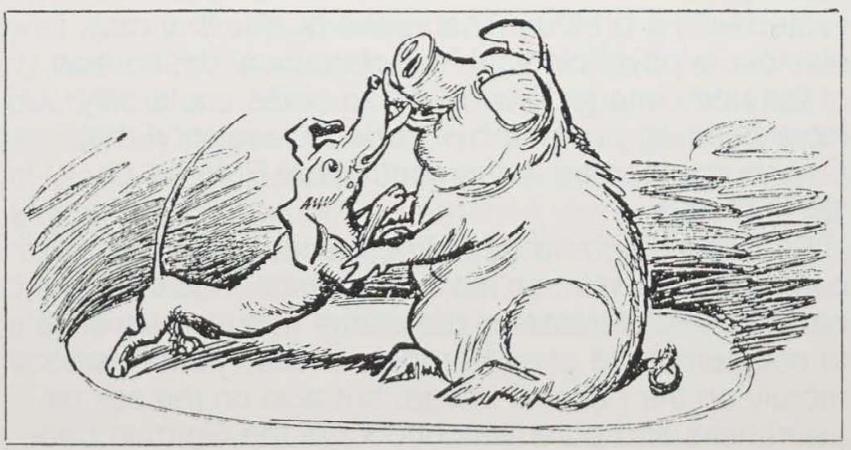




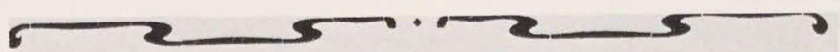

\section{Paragraph 175.}

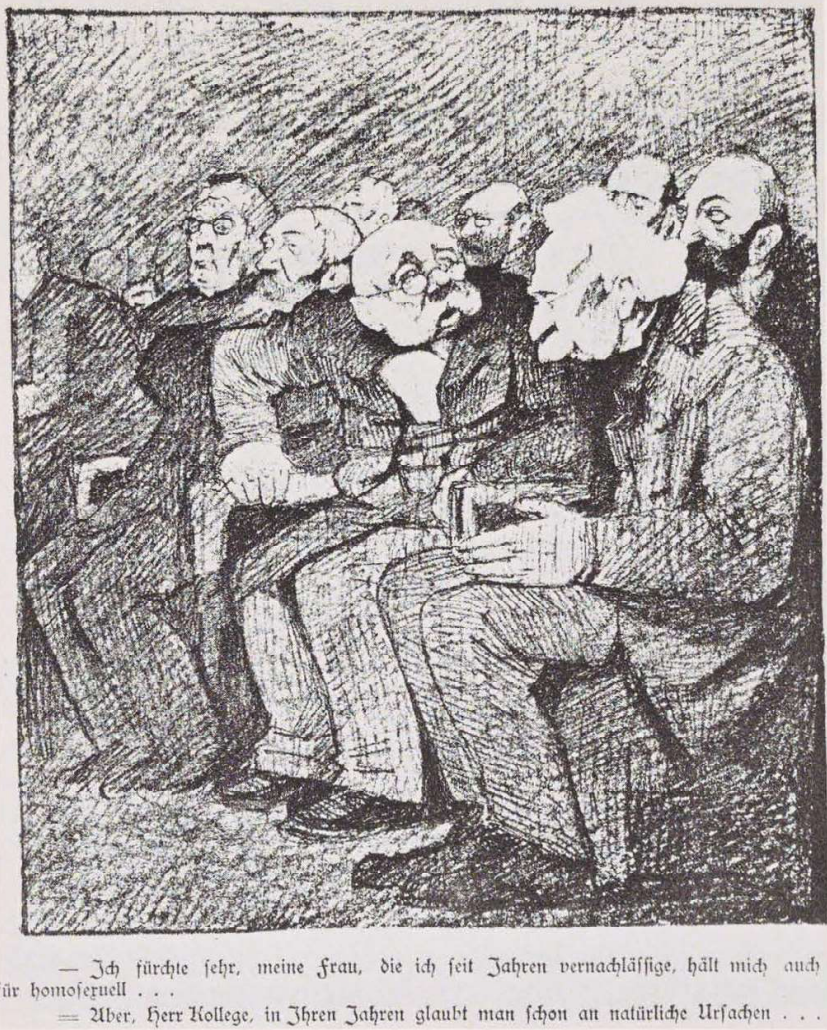

Figure 39 (caption above) Paragraph 175. (caption below) "I'm quite afraid that my wife, whom I've been neglecting for years, may now regard me as homosexual. ..." "Come, come, old chap, in a man of your age it will be attributed to natural causes." From Wiener Caricaturen (Vienna), vol. 27, no. 44 (November 3, 1907), p. 8.

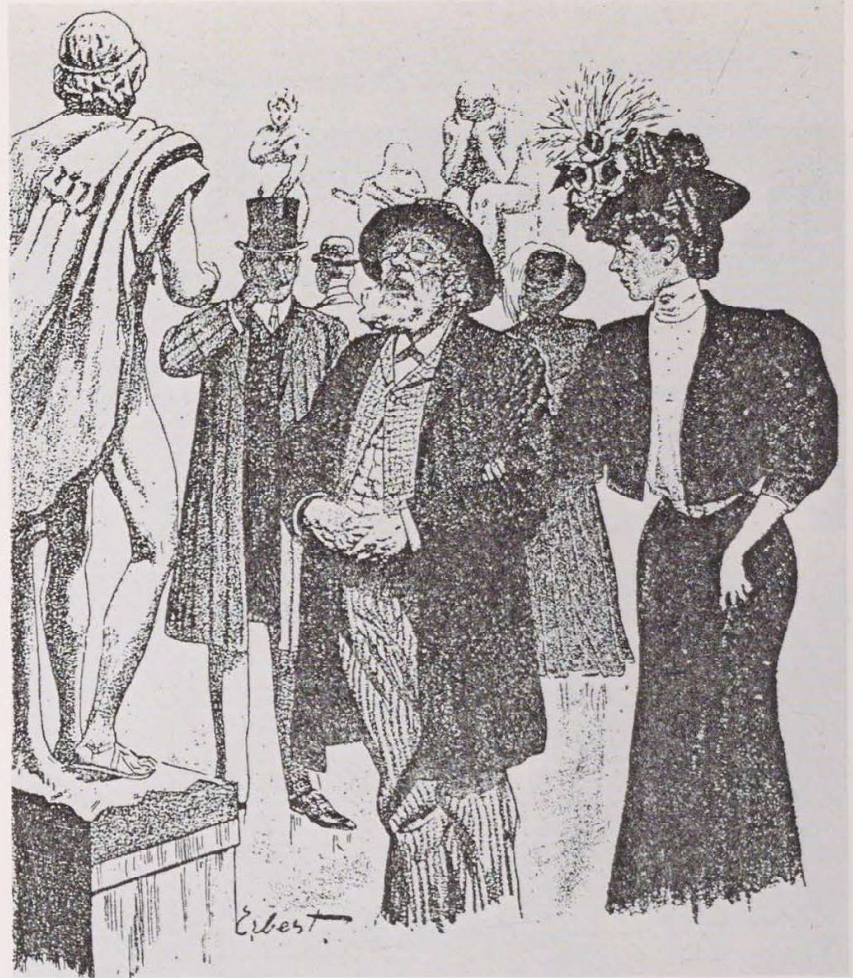

Figure 40 (caption above) Stimulus. (caption below) Father: "The beauty of the male figure far surpasses that of the female." Daughter: "What, papa, you too?" From Schalk (Leipzig), November 1907.

vested with a profoundly atavistic quality that may disclose a psychological fear of magical destruction of the body image; if so, such anxieties could only have been aggravated by Harden's revelation that Eulenburg dabbled in the occult (see Röhl 1976:47-52).

By describing and depicting homosexuality as unnatural, subhuman, animalistic - in short, as the radical Other-defenders of the status quo were striving to counteract the scandal's deleterious effects, not merely on the national image, but also on the sexual awareness and potential conduct of the German people. Commentators repeatedly lamented the loss of innocence precipitated by unprecedented discussion of sexual matters. The cartoons themselves offered something qualitatively new: the first depictions in public circulation of homosexuals. ${ }^{65}$ Lily von Elbe spoke for many when she testified that she had not suspected her then husband of homosexuality because its very existence had been unknown to her, and one editorialist contrasted the small "circle of cognoscenti" with "the vast majority of people who heretofore knew nothing of all this." 66 Even Ernst confessed that he knew "no real name" for "it." With the courtroom extraction of sexual truths and the virtually unimpeded flow of journalistic reportage (see Figure
21), newspapers began to take on a pornographic quality. Smut had been defined by a Reichstag commission in 1904 as a psychic danger to the community, certain to confuse the hearts and minds of young people and thus lead to a loss of idealism and to moral decay (Germany 1904:2308-2309). When a Reichstag delegate complained that one could no longer leave a newspaper lying where it could be found by children, ${ }^{67}$ one paper protested that it was sadly compelled to print the news and helpfully suggested that family fathers simply remove the offensive pages. ${ }^{68}$

It is fair to say that, for at least a few months, the Eulenburg Affair brought homosexuality to the forefront of national discussion, prompting individuals to reflect on themselves and others in light of new knowledge. In one of his numerous case studies, Hirschfeld reported on a woman who correctly surmised her husband's homosexual orientation after reading about Moltke's marriage (Hirschfeld 1908d:22-23), and this sort of family crisis also found its way into cartoons (see Figure 39). Attitudes and forms of behavior that had earlier been quite acceptable now became suspect (see Figure 40), and parents were reluctant to allow their sons to enter the military or even to move from the country to the city 


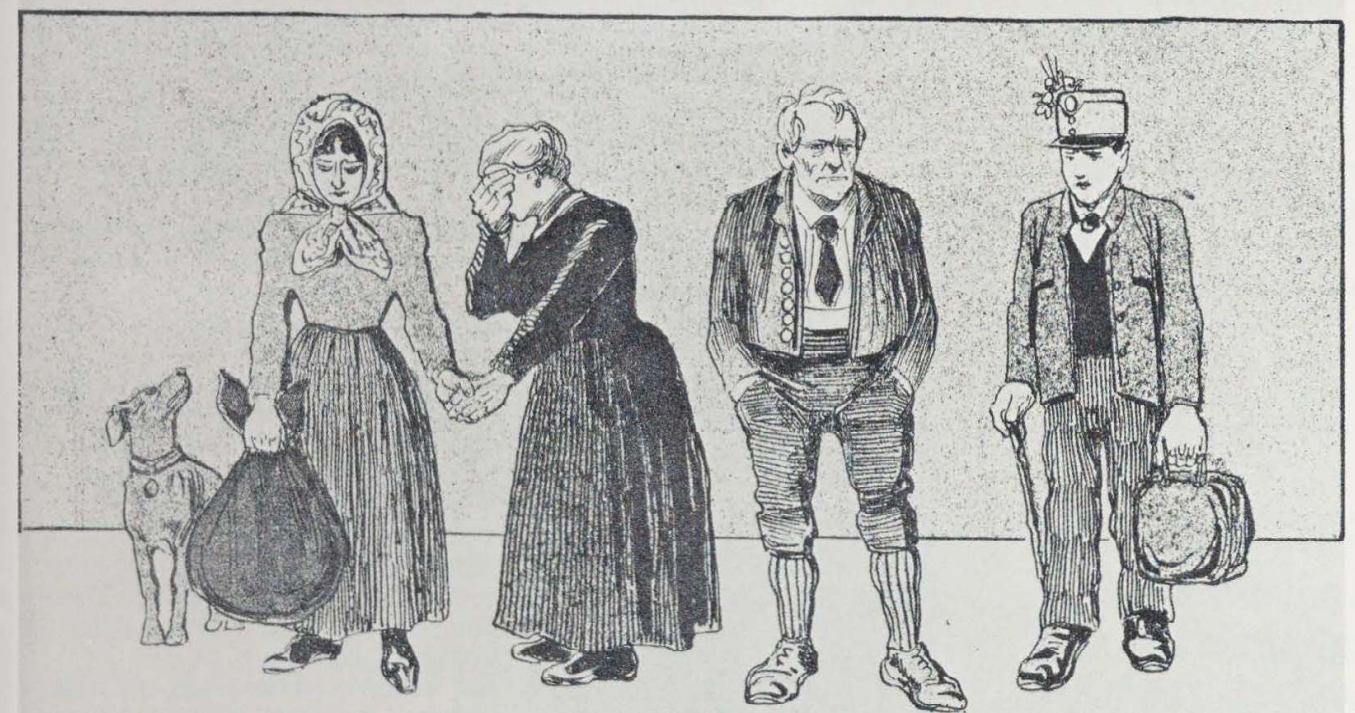

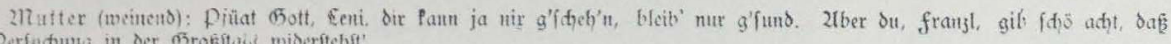

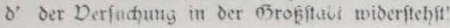

Figure 41 (caption above) In the Country. (caption below) Mother (weeping): "Farewell, Leni, nothing can happen to you, just be well. But you, Franz, watch out that you withstand temptation in the big city." From Der Floh (Vienna), undated special issue on Paragraph 175 (ca. November 1907), p. 8.

(see Figure 41). ${ }^{69}$ One Reichstag delegate expressed the most deep-seated fear when he argued: ${ }^{70}$

There can be no doubt that many hundreds and thousands of people who earlier hadn't the foggiest notion of the things now being discussed in public will, after having been enlightened about these things, be tempted to try them out with their own bodies.

With rare directness, this politician's remark points to what Foucault has described as the nub of sexual politics: "the fact that sex is located at the point of intersection of the discipline of the body and the control of the population" (Foucault 1980:125).

The biopolitical aim of the cartoons - as of the discourses that linked homosexuality with treason and the heightened enforcement of Paragraph 175 - was the total suppression of homosexuality. But, paradoxically, these images, discourses, and practices may well have incited many individuals to follow through on desires they had heretofore ignored or suppressed; indeed, desire itself may have been created. And, for others who had led double lives up to this point, the scandal led to a new possibility for conceptualizing their secret vices and arriving at a fundamentally new identity. If this be true, then Hirschfeld was simply wrong when he claimed that homosexuality was no more widespread in the present than in the past. Thus, the effect of the Eulenburg Affair was not exclusively repressive; despite its role in the outbreak of World War I, despite the campaign for moral rearmament, the anti-Semitic undertones, the heightening of military discipline, the concern about decadence, and the exhortations of middle-class morality, a subtle dialectic was at work tending to proliferate sexual practices and identities. 


\section{Acknowledgment}

Early versions of this essay were presented at the Wilde '82 conference in Toronto on June 30, 1982 , and at the Social Science History Association convention in Bloomington on November 12, 1982; I would like to thank James Fraser, Alan Miller, and Allan Megill for arranging critical forums. The essay also benefited from suggestions by Jess Anderson, Isabel Hull, Jim Jones, Nancy Kaiser, Biddy Martin, George Mosse, Yvonne Ozello, John Tallman, and Sally Winkle. Manfred Herzer, Hans-Günter Klein, and Fred Sommer helped locate cartoons in West Berlin and Vienna. Finally, research was aided by a grant from the Universität Bremen, for which I am indebted to Professor Rüdiger Lautmann.

\section{Notes}

1 In a speech on November 28, 1907, by Chancellor Bülow (Germany 1908a:1880)

2 Harden never fully disclosed the evidence he could bring to bear in order to force "a change of imperial personnel," but in a letter to Friedrich von Holstein dated November 15, 1908, he broadly hinted that his "trump" was Jakob Ernst, who later figured so prominently in the Eulenburg perjury trial (see Holstein 1963:no. 1151). In a part of this letter inexplicably omitted by the editors of The Holstein Papers, Harden also linked the kaiser with Eulenburg's private secretary and masseur, Karl Kistler; this passage appears in Hull 1982b:141. This evidence has been summarized and discussed in Röhl 1982:48

3 Thus Germany has produced a monograph on the Daily Telegraph scandal, but none on the Eulenburg scandal (cf. Schüssler 1952).

4 In a letter dated September 8, 1927, to Fritz-Wend Prince zu Eulenburg, quoted in Röhl 1976:46.

5 Particular importance attaches to these ephemera because of enormous gaps in the documentary record. Eulenburg and others implicated in the scandal assiduously burned personal correspondence that might be subpoenaed, and all the evidentiary material collected during the course of his perjury trial was mysteriously destroyed by the Prussian Ministry of Justice in 1932 (Röhl 1976:35).

6 These political cartoons generally appeared not in the daily newspapers themselves but in separate, profusely illustrated weekly or biweekly periodicals ("Witzblätter"), of which some were autonomous (Die Jugend and Simplicissimus, for example) while others were editorially controlled by newspaper publishers (such as Kladderadatsch, published by Rudolf Mosse, or Der wahre Jacob, published by the Social Democratic party).

7 This remark was attributed to Wilhelm von Liebenau by Herbert von Bismarck in a letter dated October 5, 1888, to his falher, Chancellor Otto von Bismarck (Bismarck 1964:523).

8 This epithet is attributed to Wilhelm II himselt, in a conversation on January 1, 1889, with his tutor, Georg Ernst Hinzpeter (quoted by Hull 1982c:202).

g Bismarck's comments are reconstructed in Harden 1913:173. For other comments on homosexuality by the Iron Chancellor, see Bismarck 1968:19-20.

10 This remark is attributed to the English diplomat Gosselin in 1895 (Röhl 1982:37)
11 Charlotte Princess von Sachsen-Meiningen is included in a list of Eulenburg's enemies in Weller 1970:179. Harden tried without success to summon Charlotte as a witness in the second Moltke v. Harden trial, claiming that she had spoken privately of Eulenburg's homosexuality (Vossische Zeitung, December 23, 1907, evening ed., no. 600, p. 3; December 27, 1907, evening ed., no. 604, p. 3). She declined to return from the Riviera to Berlin and had her courier express astonishment that her name had been dragged into the affair.

12 This remark was attributed to Edgard Count von Wedel, chamberlain of Wilhelm II, in a diary entry dated June 17, 1907, by Hans von Tresckow, head of the Berlin vice squad. See Tresckow 1922:183; Wedel's homosexuality is discussed on pp. 142-143 of the same work.

13 On the role of Jews in German journalism, see Pulzer 1964:13. On Harden's use of the term "effectiveness," see Young 1959:104.

14 At the opening session of the first Moltke v. Harden trial, Harden briefly described his career and criminal record: he had twice served six-month jail sentences for lèse majesté (Vossische Zeitung, October 23, 1907, evening ed., no. 498, p. 2).

15 On Harden's use of the name Tütü, see Young 1959:89. In the first Moltke v. Harden trial, Moltke testified that Tütü had been his nursery nickname and was still used by two of his sisters (Vossische Zcitung, October 23, 1907, evening ed., no. 498, p. 3).

16 One instance of the word "sweet" denoting homosexuals is Linden 1909. Note also that when Harden was convicted of libel in his second trial against Moltke, the court's decision was based in part on his use of "der Süsse" for Moltke. This epithet, taken together with his use of the word "warm." was interpreted by the court as synonymous with "homosexual" in the vernacular (Vossische Zeitung, January 4, 1908, morning ed., no. 5, 1. Beilage, p. 3).

17 The dialogue is amusingly cast in the form of a travesty of the "Nacht. Offen Feld" scene of Goethe's Faust.

18 This piece originally appeared as a newspaper article in 1907 and was reprinted as a pamphlet in 1914.

19 On the events leading up to the selection of the crown prince to inform the kaiser, see Hirschfeld 1907a

20 On the list of homosexuals kept by the Berlin police, see Tresckow 1922:164-165.

21 This account of the first day of the trial is based on the reports in the Vossische Zeitung, October 23, 1907, evening ed., no. 498, pp. 2-3, October 24, 1907, morning ed., no. 499, 5. Beilage, p. 1.

22 Vossische Zeitung, October 24, 1907, evening ed., no. 500, pp. 2-3.

23 Vossische Zeitung, October 25, 1907, evening ed., no. 502, p. 3. Hirschfeld's testimony also appears in Hirschfeld 1907b:213-214.

24 It might well be argued that the judiciary was in no position to act on its own initiative, i.e., without instructions from the kaiser or the chancellor. Still, Harden himself altributed the change in his fortunes in part to the machinations of the judiciary; see his correspondence in Holstein 1963:nos. 1060, 1061, 1063, 1065, 1066.

25 On the differences between Hirschfeld and Brand, see Hohmann 1981:309-344.

26 Vossische Zeitung, November 6, 1907, evening ed., no. 522, pp 2-4, and November 7, 1907, morning ed., no. 523, 5. Beilage, p. 1 Years after he had served his libel sentence, Brand bitterly maintained the truth of his original allegations and moreover added the charge that Bülow had more recently had a sexual affair with the pianist Karl Tausig; see the review of Bülow's memoirs, Brand 1930:49-52

27 Vossische Zeitung, November 6, 1907, evening ed., no. 522, p. 3.

28 Since the assertion that Hirschfeld may have perjured himself is a serious charge, an aside is in order. Brand testified that he had learned of Bülow's homosexuality from (among others) Joachim Gehlsen, the editor of Die Reichsglocke, who in turn testified that his source was Hirschfeld. Hirschfeld argued that, while he had informed Gehlsen of various cases of homosexual blackmail-as he would inform any journalist - the question of Bülow's sexual orientation had never come up. A few weeks later, Hirschfeld pressed 
charges of slander and blackmail against Gehlsen. The case, however, was never tried because of Gehlsen's unexpected and premature death. It seems likely that Gehlsen sought to blackmail Hirschfeld by threatening to expose his perjury. For Hirschfeld's side of the dispute, see Hirschfeld 1907d:232-237; 1908d:17-20; and 1913:863-864

29 Although the trial was conducted in closed session, testimony routinely appeared verbatim in the newspapers. See the Vossische Zeitung, from December 20, 1907, morning ed., no. 595 through January 4, 1908, morning ed., no. 5.

30 On the court-martial of Hohenau and Lynar, see the Vossische Zeitung, January 22-24, 1908.

31 Since the perjury trial of Eulenburg was never concluded, this judgment may seem unduly harsh. It is indeed possible that Eulenburg never violated Paragraph 175 , as he claimed. Since the law penalized "unnatural vice" and this vague phrase was generally construed by the courts to apply only to anal intercourse, Eulenburg may have been technically innocent of violating the law by virtue of having engaged only in other sexual practices. Indeed, this is apparently why Hohenau was acquitted in his court-martial. But Eulenburg had blundered by testifying that he had never engaged in any "filth" whatsoever, for this word was interpreted by the state prosecutor to include the full range of homosexual practices. Newspapers avoided going into detail on this aspect of Eulenburg's perjury trial, although it occupied the lawyers for days. For a singularly explicit treatment of these and related issues, see Casper 1907.

32 The suggestion was made by Axel von Varnbüler; see Röhl 1976:42.

33 This lack of interest is suggested by the rapid decline in the number of political cartoons elicited by the various trials.

34 The Social Democratic concern about a possible double standard was revealed in print, in Reichstag speeches, and in cartoons. See August Bebel's Reichstag speech in Germany 1908a:1907-1910; Mehring 1907:145-148; and the cartoon on the double standard in Der wahre Jacob, no. 570 (May 26, 1908), p. 583.

35 Vossische Zeitung, July 7, 1908, evening ed., no. 314, p. 3.

36 On the keyhole incident, see Vossische Zeitung, July 11, 1908, morning ed., no. 321, 1. Beilage, p. 2.

37 This is in an unpublished letter dated April 5, 1909 to Albert Ballin (quoted by Röhl 1976:44).

38 Harden made this statement in a conversation with Magnus Hirschfeld (see Weller 1970:161).

39 Vossische Zeitung, October 27, 1907, morning ed., no. 505, p. 1

40 Ernst Bassermann, delegate of the National Liberal party, on November 18, 1907 (in Germany 1908a:1889).

41 See the French and Italian cartoons reproduced in Hirschfeld 1930:275, 279, 299

42 This parallel is shown with remarkable clarity in two Social Democratic cartoons - one from 1907, the other from 1931 -repro duced in Eissler 1980:45 and 109. On Hitler's awareness of the parallel, see Wagener 1978:200. For Hirschfeld's standpoint, see his last published article, Hirschfeld 1934.

43 For a summary of the discussion of Goethe in volumes two through nine of the Jahrbuch für sexuelle Zwischenstufen, which Hirschfeld edited, see Birnbaum 1908:179-181; see also Katte 1908:445-447.

44 See, for example, the Reichstag speech on November 28, 1907. by Wilhelm August Otto Varenhorst of the Deutsche Reichspartei (in Germany 1908a:1889).

45 See, for example, Otto Glagau's remarks in Die Gartenlaube in 1876 (as quoted in Pulzer 1964:89)

46 Hirschfeld thus paraphrases an editorial entitled "Rattenkönig" from the July 3, 1908, issue of März (Hirschfeld 1908c:512).

47 Stöcker's March 3, 1906, speech appears in Germany 1906:1712

48 For some early documentation on uniform fetishism, see Symonds 1896:285-304, an excursus that was omitted from all subsequent English editions of Sexual Inversion; and Ulrichs 1898c:48;

1898b:47-48; 1898a:101-103.
49 Vossische Zeitung, October 27, 1907, morning ed., no. 505, 13. Beilage, p. 4.

$50 \mathrm{Ibid}$. What Harden deposed on October 27 had already been en tered in H. von Tresckow's diary on September 3 (see Tresckow 1922:185).

51 His speech of November 19, 1907, appears in Germany 1908a:1913ff.

52 Vossische Zeitung, October 26, 1907, evening ed., no. 504, p. 3.

53 In a letter dated September 17, 1904, to Nathaniel Rothschild (quoted in Röhl 1976:37)

54 In a letter by Axel von Varnbüler dated April 15, 1898 (quoted in Röhl 1976:40)

55 Vossische Zeitung, November 6, 1907, evening ed., no. 522, p. 2

56 Vossische Zeitung, December 31, 1907, morning ed., no. 609, 1 Beilage, p. 2.

57 Isabel V. Hull is presently researching social class and the political use of sex in Germany, 1780-1870. For a useful contribution, see Holub 1981

58 See the treatment of the views of Friedrich von Bodelschwingh in Hull 1982a:252-253.

59 Dr. Siegfried Heckscher, a Reichstag delegate of the Freisinnige Vereinigung, made these points in an article in the Hamburger Fremdenblatt, October 31, 1907. The article is reprinted in its entirety in the more accessible Sexualreform (cf. Heckscher 1907).

60 The German for "master race" is "Herrenvolk"; Harden (1913) also speaks of homosexuality as a "danger to the race" ("Rassengefahr") on p. 183

61 The number of convictions under the same-sex provisions of Paragraph 175 (for the law also penalized bestiality) increased nearly fifty percent in the wake of the Eulenburg scandal. In the five-year span 1903-1907, the annual average was 363 convictions; the average rose to 542 in the years 1909-1913. In 1908, the number dropped to 282, a decrease that Magnus Hirschfeld may have accounted for when he noted that homosexuals were probably especially cautious during the height of the scandal (Hirschfeld 1908a:53). The statistics are extracted from Klare 1937:144-145.

62 Vossische Zeitung, November 6, 1907, evening ed., no. 522, p. 3

63 Vossische Zeitung, October 23, 1907, evening ed., no. 498, p. 3.

64 Vossische Zeitung, December 24, 1907, morning ed., no. 601, 1. Beilage, p. 3.

65 This point was first made by Grand-Carteret 1908:59. There were earlier images of homosexuals, but these high-art images were highly restricted in circulation; see Beurdeley 1978 for a representative collection. Other early images, such as the broadsides on executions of sodomites, were more widely distributed but usually lacked any specifically homosexual quality; see, for example, Bray 1982:15, 94-95.

66 Vossische Zeitung, October 27, 1907, morning ed., no. 505, p. 1.

67 National Liberal delegate Ernst Bassermann, in a speech on November 28, 1907 (in Germany 1908a:1890).

68 Vossische Zeitung, October 27, 1907, morning ed., no. 505, p. 1

69 The argument concerning the military was made by Center party delegate Peter Spahn in a Reichstag speech on November 18 , 1907 (Germany 1908a:1875).

70 In a Reichstag speech on February 20, 1908, by W. A. O. Varenhorst (Germany 1908b:3299). 


\section{References}

\section{- Baumont, Maurice}

1933 L'Affaire Eulenburg et les origines de la Guerre Mondiale Paris: Payot. 2d rev. ed., Geneva: Edito-Service, 1973.

- Balfour, Michael

1964 The Kaiser and His Times. Boston: Houghton Mifflin

- Beurdeley, Cecile

1978 L'Amour bleu. Michael Taylor, tr. New York: Rizzoli.

- Beyerlein, Franz Adam

1914 "Jena" or "Sedan"? New York: George H. Doran. Orig. ed. 1903.

1915 Taps. Charles Swickard, tr. Boston: John W. Luce. Orig. ed 1903

- Bilse, Lt. Fritz Oswald

1904 Life in a Garrison Town. New York and London: John Lane, The Bodley Head. Orig. ed., 1903.

- Birnbaum, Max

1908 Notizen aus Goethes Werken über Homosexualität. Zeitschrift für Sexualwissenschaft 1:179-181.

- Bismarck, Herbert von

1964 Staatssekretär Herbert von Bismarck: Aus seiner politischen Privatkorrespondenz. Walter Bussmann and Klaus-Peter Hoepke, eds. Göttingen: Vandenhoeck \& Ruprecht.

- Bismarck, Otto von

1968 Reflections and Reminiscences. Theodore S. Hamerow, ed New York: Harper \& Row.

- Blümner, Rudolf

1910 L'Amour à l'allemande. Der Sturm 10:1/9-180.

- Brand, Adolf

1930 Tante Reichskanzler. Eros 2:49-52.

$1975 \$ 175$. In Documents of the Homosexual Rights Movement in Germany, 1836-1927. New York: Arno. Orig. ed., 1907.

- Bray, Alan

1982 Homosexuality in Renaissance England. London: Gay Men's Press.

- Bullough, Vern L.

1976 Homosexuality and the Medical Model. In Sex, Society, and History. Pp. 161-172. New York: Science History Publications.

- Casper, J.L.

1907 Das Treiben der Homosexuellen: Volle Aufklärung zum Verständnis der Andeutungen und "halben Worte" im MoltkeHarden Prozess. Leipzig: Leipziger Verlag.

- Cole, Terence F

1982 The Daily Telegraph Affair and Its Aftermath. In Kaiser Wilhelm II: New Interpretations. John C. G. Röhl and Nicolaus Sombart, eds. Pp. 249-268. Cambridge: Cambridge University Press.

- Czernin von und zu Chudenitz, Ottokar

1919 In the World War. London and New York: Cassell.

- Eissler, W. U.

1980 Arbeiterparteien und Homosexuellenfrage: Zur Sexualpolitik von SPD und KPD in der Weimarer Republik. West Berlin Verlag rosa Winkel.

- Eulenburg, Philipp zu

1931 Mit dem Kaiser als Staatsmann und Freund auf Nordlandreisen, Vol. 2. Dresden: Carl Reissner.

- Evans, Richard J

1976 The Feminist Movement in Germany, 1894-1933. London and Beverly Hills: Sage.

- Foucault, Michel

1978 The History of Sexuality, Vol. 1: An Introduction. Robert Hurley, tr. New York: Pantheon

1980 Power/Knowledge. Colin Gordon, ed. New York: Pantheon

- Frank, Walter

1942 Höre Israel. Hamburg: Hanseatische Verlagsanstalt.

- Germany (government)

1904 Stenographische Berichte über die Verhandlungen des Reichstags, Vol. 208. Anlageband.

1906 Stenographische Berichte über die Verhandlungen des Reichstags, Vol. 215. January 31-March 6, 1906.
1908 a Stenographische Berichte über die Verhandlungen des Reichstags, Vol. 229. November 22, 1907-January 20, 1908.

$1908 \mathrm{~b}$ Stenographische Berichte über die Verhandlungen des Reichstags, Vol. 230. January 21-February 27, 1908.

- Grand-Carteret, John

1908 Derrière "Lui." Paris: E. Bernard

- Harden, Maximilian

1905 Kommerzienrath Israel. Die Zukunft 53:311-315.

1906a Praeludium. Die Zukunft 57:251-266.

1906b Dies irae. Die Zukunft 57:287-302.

1907a Roulette. Die Zukunft 59:117-130.

1907b Nur ein paar Worte. Die Zukunft 59:367-374.

1907c Die Freunde. Die Zukunft 59:405-425

1913 Fürst Eulenburg. In Köpfe, Vol. 3: Prozesse. Pp. 169-283. Berlin: Erich Reiss.

- Hartleben, Otto Erich

1900 Rosenmontag. Offiziers-Tragödie in fünf Akten. Berlin: S. Fischer.

- Heckscher, Siegfried

1907 \$175. Sexualreform 2:362-364.

- Hentschel, Wilhelm

1909 Die Ursachen der Gleichgeschlechtlichkeit. Politisch-anthropologische Revue 8:92-94.

- Hirschfeld, Magnus

$1907 a$ Die Hofaffäre. Monatsbericht des wissenschaftlich-humanitären Komitees 6 (July 1):126-134.

190/b Komiteeangelegenheiten. Monatsbericht des wissenschaftlich-humanitären Komitees 6 (November 1):209-215.

1907c Wessen Schuld? Allgemeinere Betrachtungen zum Prozess Moltke-Harden. Der Roland von Berlin 5 (November 7):1519-1523

1907d Zur Klärung. Monatsbericht des wissenschaftlich-humanitären Komitees 6 (December 1):229-242.

1908a Materialien. Zeitschrift für Sexualwissenschaft 1 (January):52-64

1908b Jahresbericht 1906/8. Jahrbuch für sexuelle Zwischenstufen 9:623-663

1908c Aus der Zeit. Zeitschrift für Sexualwissenschaft 1 (August):509-512.

1908d Sexualpsychologie und Volkspsychologie: Eine epikritische Studie zum Harden-Prozess. Leipzig: Georg H. Wigand

1909 Einleitung und Situations-Bericht. Jahrbuch für sexuelle Zwischenstufen 10:3-30.

1913 \$175. Pan 2:863-864

1930 Sittengeschichte des Weltkrieges. 2 vols. Leipzig and Vienna: Verlag für Sexualwissenschaft Schneider.

1933 Vor fünfundzwanzig Jahren. Freundschaft 15:2 5

1934 Röhm und Genossen. Volk, July 17, no. 164, Beilage, p. 1

- Hohmann, Joachim S.

1981 "Der Eigene," seine Urheber und inre Geschichte. In Der Eigene. J. S. Hohmann, ed. Pp. 309-344. Frankfurt and Berlin: Foerster.

- Holstein, Friedrich von

1963 The Holstein Papers, Vol. 4: Correspondence, 1897-1909. Norman Rich and H. M. Fisher, eds. Cambridge: Cambridge University Press.

- Holub, Robert C.

1981 Heine's Sexual Assaults: Towards a Theory of the Total Polemic. Monatshefte 73:415-428.

- Hull, Isabel V.

$1982 \mathrm{a}$ The Bourgeoisie and Its Discontents: Reflections on "Nationalism and Respectability. "Journal of Contemporary History 17:247-268

1982b The Entourage of Kaiser Wilhelm II, 1888-1918. Cambridge: Cambridge University Press

1982C Kaiser Wilhelm II and the "Liebenberg Circle." In Kaiser Wilhelm II: New Interpretations. John C. G. Röhl and Nicolaus Sombart, eds. Pp. 193-220. Cambridge: Cambridge University Press. 
- Igra, Samuel

1945 Germany's National Vice. London: Quality.

- Institut zum Studium der Judenfrage

1936 Die Juden in Deutschland. Munich: Ehler.

- Katte, Max

1908 Schillers "Malteser" - ein homosexuelles Dramenfragment. Zeitschrift für Sexualwissenschaft 1:445-447.

- Katz, Jonathan

1983 Gay/Lesbian Almanac. New York: Harper \& Row.

- Kettle, Michael

1977 Salome's Last Veil: The Libel Case of the Century. London: Granada.

- Klare, Rudolf

1937 Homosexualität und Strafrecht. Hamburg: Hanseatische Verlagsanstalt.

- Kokula Ilse

1981 Weibliche Homosexualität um 1900 in zeitgenössischen Dokumenten. Munich: Frauenoffensive

- Kurtz, Harold

1970 The Second Reich. London: Macdonald.

- Linden, Karl Friedrich

1909 Die Süssen: Ein Berliner Roman. Budapest: G. Grimm.

- Linsert, Richard

1931 Kabale und Liebe. Berlin: Man.

- Mehring. Franz

1907 Der Prozess Moltke-Harden. Die neue Zeit 26:145-148.

- Mosse, George L.

1982 Nationalism and Respectability: Normal and Abnormal Sexuality in the Nineteenth Century. Journal of Contemporary History 17:221-246.

- Nye, Robert A.

1982a Degeneration and the Medical Model of Cultural Crisis in the French Belle Epoque. In Political Symbolism in Modern Europe: Essays in Honor of George L. Mosse. Pp. 19-41. New Brunswick, NJ: Transaction.

1982b Degeneration, Neurasthenia and the Culture of Sport in Belle Époque France. Journal of Contemporary History 17:51-68.

- Pulzer, Peter G.

1964 The Rise of Political Anti-Semitism in Germany and Austria. New York: John Wiley.

- Röhl, John C. G.

1976 Einleitung. In Philipp Eulenburgs politische Korrespondenz, Vol. 1. Pp. 9-75. Boppard am Rhein: Harald Boldt

1982 The Emperor's New Clothes: A Character Sketch of Wilhelm II. In Kaiser Wilhelm II: New Interpretations. J. C. G. Röhl and Nicolaus Sombart, eds. Pp. 23-61. Cambridge: Cambridge University Press.

- Schivelbusch, Wolfgang

1979 The Railroad Journey: Trains and Travel in the Nineteenth Century. New York: Urizen.

- Schüssler, Wilhelm

1952 Die Daily-Telegraph-Affaire. Göttingen: Musterschmidt.

- Stöcker, Helene

1908 Der Prozess Eulenburg und die Sexualwissenschaft. Die neue Generation 4:285-288.

- Symonds, John Addington

1896 Soldatenliebe und Verwandtes. In Das konträre Geschlechtsgefühl. Havelock Ellis and J. A. Symonds. Hans Kurella, tr. Pp. 285-304. Leipzig: Georg H. Wigand.

- Tresckow, Hans von

1922 Von Fürsten und anderen Sterblichen: Erinnerungen eines Kriminalkomissars. Berlin: F. Fontane.

- Ulrichs, Karl Heinrich

1898a Ara spei. Leipzig: Max Spohr. Orig. ed., 1864

1898b Formatrix. Leipzig: Max Spohr. Orig. ed., 1864

1898c Inclusa. Leipzig: Max Spohr. Orig. ed., 1864.

- Wagener, Otto

1978 Hitler aus nächster Nähe. H. A. Turner, ed. Frankfurt: Ullstein.

- Weindel, Henri and Fischer, F. P.

1908 L'Homosexualité en Allemagne. Paris: Juven.
- Weller, B. Uwe

1970 Maximilian Harden und die "Zukunft." Bremen: Carl Schünemann

- Wilhelm

1922 Memoirs of the Crown Prince of Germany. New York: Charles Scribner's Sons.

- Young, Harry F.

1959 Maximilian Harden: Censor Germaniae. The Hague: Martinus Nijhoff.

- Zedlitz-Trützschler, Robert von

1924 Twelve Years at the Imperial German Court. Alfred Kalisch, tr. New York: George H. Doran. 